\title{
New late Oligocene rodent faunas from the Pannonian basin
}

\author{
Andrew A. van de Weerd ${ }^{1}$ (D) $\cdot$ Hans de Bruijn ${ }^{1} \cdot$ Wilma Wessels $^{1}$ (i) $\cdot$ Zoran Marković $^{2}$ \\ Received: 3 July 2020 /Revised: 16 December 2020 / Accepted: 11 February 2021 / Published online: 23 September 2021 \\ (C) The Author(s) 2021
}

\begin{abstract}
The rodent associations from the late Oligocene deposits of Ugljevik and Paragovo in the Pannonian basin are described. Pannoniamys paragovensis, a new genus and species of Spalacidae, is defined. The published data from a third late Oligocene locality in the area (Banovići) is included in the discussion of the changes in community structure through the time-interval studied. Although the composition of the rodent faunas studied differs, the dominating cricetid genus in all three associations is Deperetomys, a genus that appears in western Europe during the late middle Miocene. While the late Oligocene rodent record of central and southwestern Europe is characterised by endemic development, the regime in the Balkans seems to have been one of multiple immigrations and replacements. The late Oligocene age of the rodent fauna from Ugljevik estimated at about $26 \mathrm{Ma}$, provides a minimum age for the start of rifting in the Pannonian basin, some $6 \mathrm{Ma}$ earlier than previously documented.
\end{abstract}

Keywords Rodentia $\cdot$ Serbia $\cdot$ Bosnia and Herzegovina $\cdot$ Gliridae $\cdot$ Eomyidae $\cdot$ Dipodidae $\cdot$ Spalacinae $\cdot$ New genus and species $\cdot$ Eucricetodon · Eumyarion · Daxneria

\section{Introduction}

Isolated findings of Eocene large mammals from several sites on the Balkans are related to Asian and not to European taxa (Nikolov and Heissig 1985; Heissig 1990; Hellmund and Heissig 1994), demonstrating the presence of a fauna province on the Balkans that is strikingly different from that of central and western Europe. The pre-Alpine seaways separating the

The author Hans de Bruijn sadly passed away during the last corrections for this article.

This article is registered in Zoobank under: urn:lsid:zoobank.org:pub: 5347CDFD-1065-4C91-B21B-380189C93FE4

Andrew A. van de Weerd

a.vandeweerd@uu.nl

Wilma Wessels

w.wessels@uu.nl

Zoran Marković

zoran.markovic@nhmbeo.rs

1 Department of Earth Sciences, University of Utrecht, POBox 80115 , 3508TC, Utrecht, The Netherlands

2 Natural History Museum, Njegoševa 51, Belgrade 11000, Serbia
Balkans from central Europe thus formed a major zoogeographic boundary during the Eocene and Oligocene, disappearing as a barrier in the Burdigalian (Meulenkamp and Sissingh 2003). Paleogene small mammals from the Balkans remained unknown, but in the early years of this century, an assemblage from the late Oligocene of Bosnia and Herzegovina was described (de Bruijn et al. 2013) and shortly after that late Eocene-early Oligocene rodent faunas from southern Serbia (Wessels et al. 2020; Marković et al. 2019 and references therein). These rodent faunas confirm the unique Eocene-Oligocene fauna province of the Balkans, entirely different from that of Central and Western Europe. So far, the information on late Oligocene rodents was restricted to the assemblage from Banovići in Bosnia and Herzegowina (de Bruijn et al. 2013); thus we are glad to report here on two more collections of similar age from the same general area, Ugljevik (Bosnia and Herzegowina) and Paragovo (Serbia; Fig. 1). The age of Banovići is determined by magneto-stratigraphy (de Leeuw et al. 2011); however, such data is absent for Ugljevik and Paragovo and their age estimates are necessarily based on the rodent-based biostratigraphy. Our working hypothesis is that the assemblage from Ugljevik is the older and the ones from Banovići and Paragovo are slightly younger. Despite the small size of the new assemblages and the different environments of deposition of the sediments that yielded the material, the three late Oligocene assemblages show an increasing European aspect over time. In the sections below, 


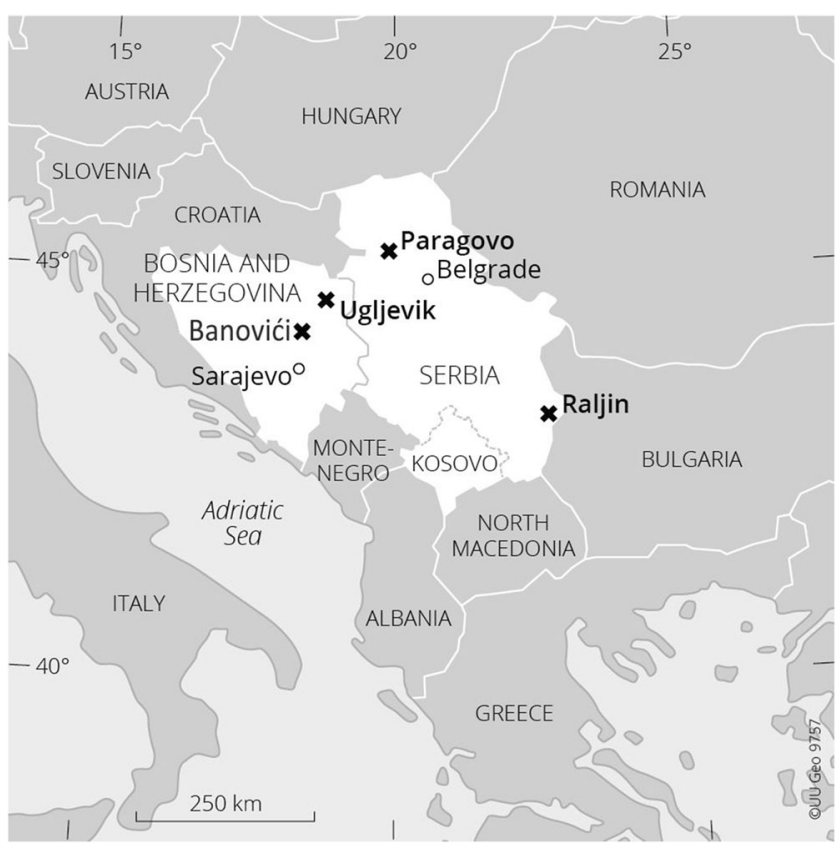

Fig. 1 Location of the Paragovo, Ugljevik, Banovići and Raljin sites

we describe the geological settings of Ugljevik and Paragovo followed by systematic palaeontology and a discussion on the biostratigraphy. One new genus and species is described; we include the genus in the Spalacidae.

\section{Geological setting of Ugljevik}

Rodents were discovered by Zoran Marković during 1993 in the cellar of the Natural History Museum in Belgrade in brown coal used for heating of the museum. The origin of the coals was traced to the town of Ugljevik in Bosnia and Herzegovina. The Bogutovo Selo mine near Ugljevik was visited during 2004 and 2005, and rodents were collected from the middle part of the main coal seam (Fig. 2). The same coal seam is exploited in the Luke-Mezgraja open pit mine, $4.5 \mathrm{~km}$ south of Bogotuvo Selo.

The area with the Bogutovo Selo and Luke-Mezgraja coal mines near Ugljevik is in the corner of four geological map sheets; the largest parts are on the sheets of Tuzla (L34-122; Čičić et al, 1988, 1991) and Zvornik (L34-123; Mojsilović et al. 1968a, b); minor parts are on the sheets of Bijeljina (L34-111; Vrhovčić et al. 1985, 1986) and Brčko (L34-110; Buzaljko et al. 1985 and Buzaljko and Marković 1985). The area is densely vegetated resulting in the near absence of natural outcrops; all lithological data presented below are from observations in the mines.

The stratigraphic unit containing the coal seams is on the geological maps identified as Miocene but later considered to be Oligocene by Vrabac et al. (1995); the stratigraphic column of the section in the Bogutovo Selo mine (Fig. 2) is adapted from these authors. The lower part of the Oligocene consists of over $50 \mathrm{~m}$ of non-marine greenish clays, marls and at places

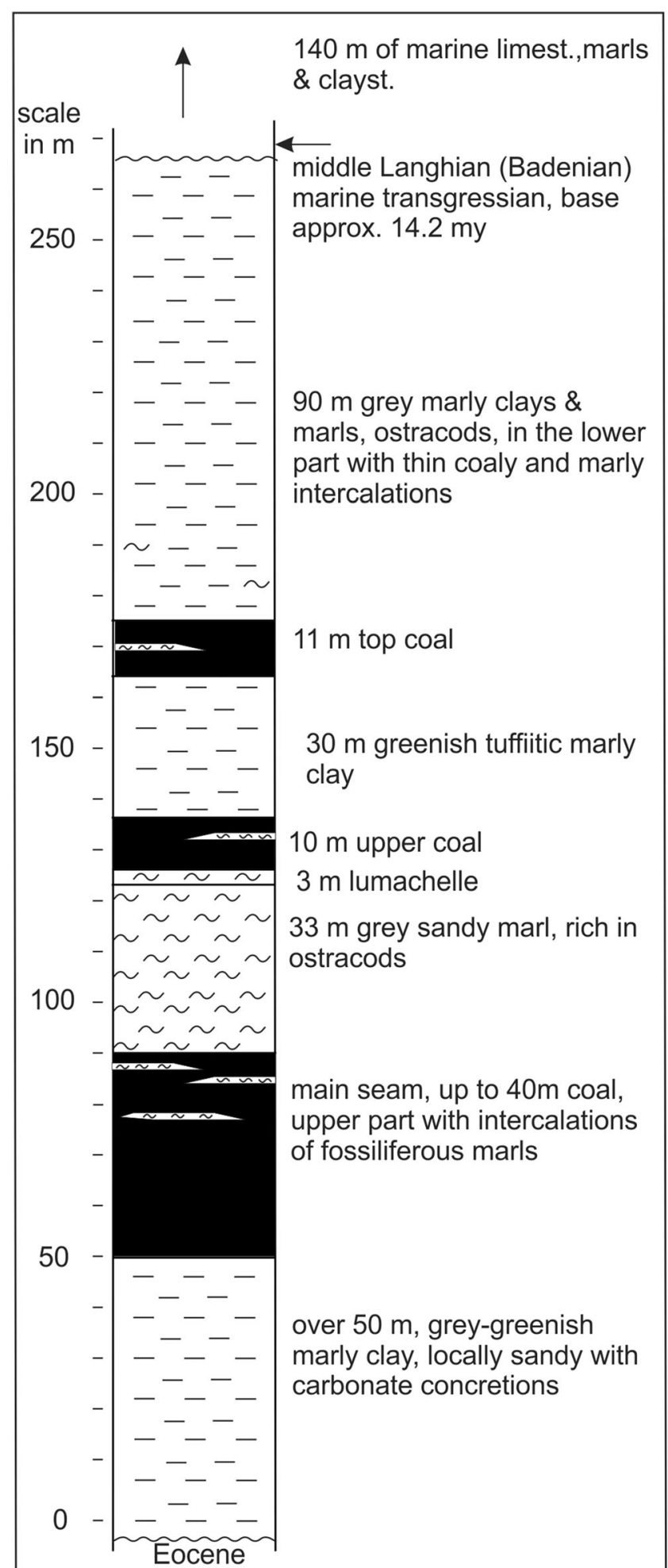

Fig. 2 Stratigraphic column of the section in the Bogutovo Selo coal mine near Ugljevik. Redrawn after Vrabac et al. (1995)

sands; in the lower part are reddish intercalations. The unit is only known from coal-exploration wells. The middle part of the upper Oligocene unit consists of coals, marls and clays. The main coal seam, mined since 1899 , is on average about $30 \mathrm{~m}$, at places up to $40 \mathrm{~m}$ thick. In the upper part of the main 
seam are many thin intercalations of marls, often with abundant molluscs. Near the top are very hard beds of silicified marl up to $15 \mathrm{~cm}$ thick. Coals are mostly semi-gloss with dull parts. Recognisable plant remains or wood remains and root traces have not been observed. Bedding planes are sharp. Levels with minute disseminated pyrite crystals occur throughout. At levels are thin intercalations with small fragments of light-brownish crushed bone fragments, presumably mostly from amphibious or aquatic vertebrates such as frogs. Rodent remains consisting of incisors with associated molars may be observed at places using the hand lens. The 20042005 rodent collection was made from the centre part of the main coal seam; the few rodents collected in 2018 are from the top of the main coal seam. Only the top of the seam in LukeMezgraja could be inspected during 2018 due to mining operations. It was not rich in fossils, and only a few Deperetomys molars were found.

Malez and Thenius (1985) described the amynodont Cadurcotherium (Rhinocerotoidea) presumably found in the main seam; Laskarev (1925) identified a $\mathrm{m} 3$ of a large mammal found at an unknown level in the mine as Anthracotherium.

The main coal seam is overlain by over $30 \mathrm{~m}$ of ostracodrich marls and a $3 \mathrm{~m}$ thick sandy marl, rich in molluses (a coquina or lumachelle). The so-called first upper coal seam with interbeds of marls and clays is variable in thickness (up to $11 \mathrm{~m}$ ) and horizontal distribution. This is followed by greenish tuffitic clay and a second upper coal with many interbeds of marls and limestone and variable horizontal distribution. Next is an about $90 \mathrm{~m}$ thick section of clays and marls capped by an unconformity.

The overlying $140 \mathrm{~m}$ of marine marls, limestones and clays is not shown in Fig. 2. This $140 \mathrm{~m}$ section has been described and investigated in detail by Pezelj et al. (2013) and Mandic et al. (2019); its base has been dated as middle Langhian suggesting a long time-hiatus at the unconformity.

\section{Geological setting of the Paragovo site in Fruška Gora}

The Paragovo site is in the Fruška Gora National Park, south of the town of Novi Sad. The location is about $550 \mathrm{~m}$ west of road 21 near the Park office (45 $15^{\circ} 40.04^{\prime \prime} \mathrm{N} ; 19^{\circ} 50^{\prime} 42.02^{\prime \prime}$ E; see Figs. 3, 4 and 5). The Fruška Gora (gora = mountain) is densely forested; outcrops are few and limited in size, located mainly in road cuts.

The Fruška Gora is an east-west-oriented tectonic uplift, about $50 \mathrm{~km}$ long and $10 \mathrm{~km}$ wide, rising several hundreds of metres above the plains of the Vojvodina region in the Pannonian basin. The uplift brings to the surface Palaeozoic serpentinites, Mesozoic sediments, intrusives and volcanics, and Tertiary sediments and intrusives. The geological map of the area is by Čičulić and Rakić (1976, 1977), sheet Novi Sad, reproduced in Toljić et al. (2013). The Paragovo site is in the north flank of Fruška Gora; it is shown in a schematic northsouth cross section (Fig. 6). The section suggests that the locality is in a small half-graben, to the north in fault contact with Triassic carbonates. Alternatively, Toljić et al. (2013) suggest emplacement of the Triassic carbonates by Pliocene thrusting. South of the Paragovo site is a thick unit of Late Cretaceous clastics described as flysch. The locality with fossil mammals is in the M1 unit of Čičulić and Rakić 1976, 1977), which consists of 250 to $300 \mathrm{~m}$ of non-marine clastics and estimated to be early Miocene (Burdigalian) in age by these authors. The M1 unit is separated from the overlying M2 unit by a hiatus; the latter unit is $100-300 \mathrm{~m}$ thick and dominantly in marine facies.

The Paragovo fossiliferous site is a small outcrop in the outer bend of a small brook (Fig. 5). It consists of 30-40 cm clay, dark brown-greenish in colour, without visible fossils. It is overlain by a sandstone of $60-70 \mathrm{~cm}$ thickness, poorly sorted, medium-grained, with at places in its base large pebbles and cobbles. The structural dip is about 60 degrees towards the NNW. In the area are few small exposures, these show poorly sorted sandy-conglomerates, suggesting rapid deposition and mass flow. Due to the absence of exposure, the stratigraphic position of the Paragovo site within the M1 unit cannot be established, but it is not near the base.

\section{Methods}

Access to the main seam in in the large Bogutovo Selo mine is difficult and dangerous during the ongoing mining operations, study of the coal section of the main seam is only possible for short periods of time. Therefore, a large amount of coal from a selected and promising horizon was conveyed by truck to a save location where it was investigated in detail. For several days, coal lumps were split with a chisel and hammer and searched for rodent remains with the naked eye and hand lens. In this way, associated incisors and molars could be collected. In addition, 200 to $300 \mathrm{~kg}$ of promising coal lumps were bagged and transported to the laboratories at the Utrecht University and the Natural History Museum in Belgrade. There, using lukewarm water with peroxide and caustic soda, coals were repeatedly washed and dried. The resulting disintegrated mixture was enriched in fossils by goldpanning followed by drying and searching under the microscope; this method yielded additional isolated teeth. During a visit in 2018, only the upper part of the main seam in Bogotuvo Selo could be inspected. This appeared less rich in fossils and only a few teeth were collected.

The fossiliferous bed in Paragovo was discovered in the spring of 2009 by Miloš Milivojević and Zoran Marković (Natural History Museum in Belgrade) when a small sample appeared to contain remains of small mammals. This triggered 


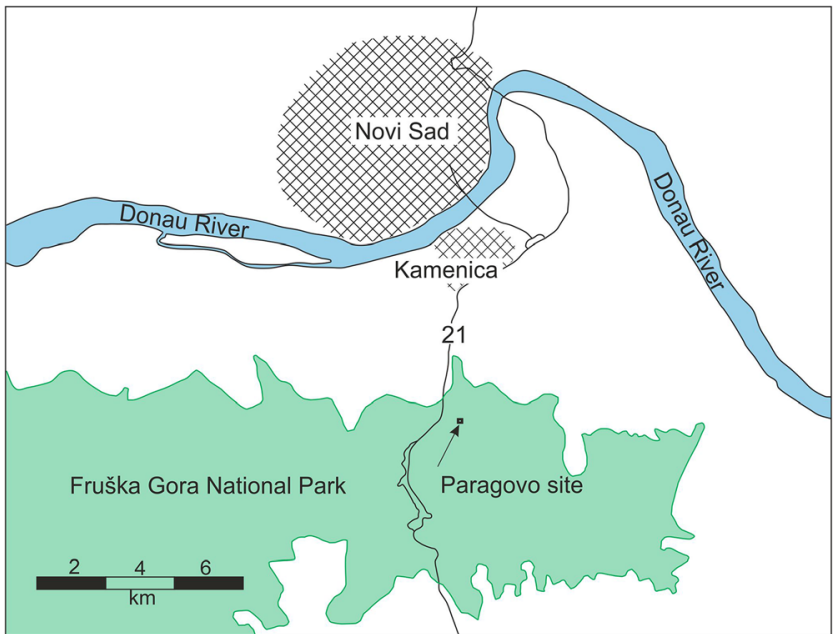

Fig. 3 Map of the Paragovo site

us to take a large sample of $\sim 2000 \mathrm{~kg}$ in the summer of 2016 that was washed and wet-screened in the field on a set of (fixed) sieves. A reasonably good, but relatively small, fauna of fossil rodents was obtained from the concentrates above $0.65 \mathrm{~mm}$; identifiable remains were not present in the partially sorted voluminous $0.65-0.5 \mathrm{~mm}$ fraction. Encouraged by this, a large sample of about $2800 \mathrm{~kg}$ was taken in 2017 . Unfortunately, the fossil content of the 2017 sample was poor, suggesting that the distribution of fossils in the clay bed is uneven.

The material described from Paragovo and Ugljevik is housed in the Natural History Museum in Belgrade. The locality codes of the Natural History Museum of Belgrade and abbreviations used for of the localities are 015 for Paragovo (PAR) and 05 for Ugljevik (UGL). The length and width of the teeth were measured with a Leitz Ortholux microscope with mechanical stage and measuring clocks.

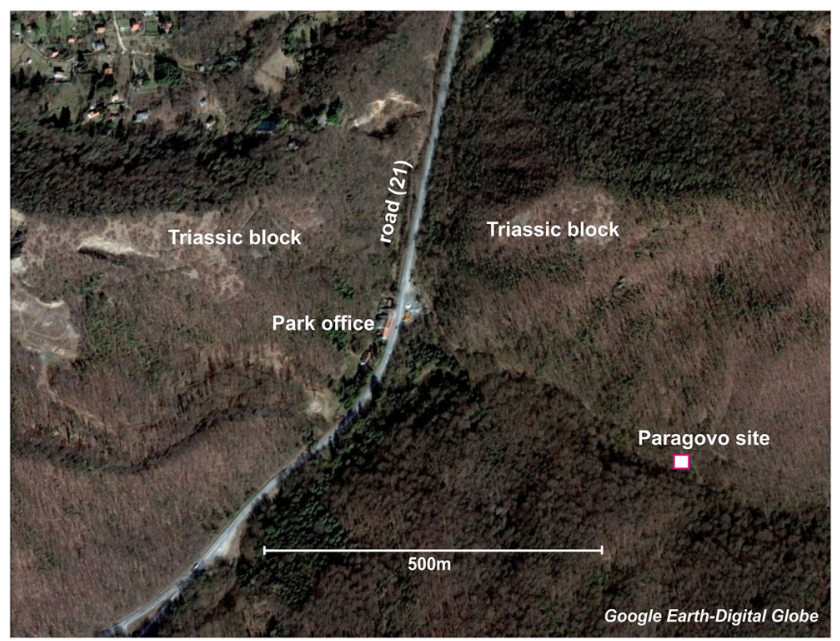

Fig. 4 Satellite image with the Paragovo site $\left(45^{\circ} 10^{\prime} 40.04^{\prime \prime} \mathrm{N}, 19^{\circ} 50^{\prime}\right.$ $\left.42.02^{\prime \prime} \mathrm{E}\right)$. The site is in a small brook at the bottom of a densely forested valley. The Triassic block is indicated in the section of Fig. 6
The measurements are given in millimetre units. The pictures were made using a table-top SEM and a high-resolution SEM. All specimens are figured as left ones, if the original is from the right side; this is indicated by underlining its number on the figure. Lower case letters refer to the lower dentition; upper case letters refer to the upper dentition. Abbreviations for measurements and descriptions are as follows: $N$, number of specimens; $R$, range of measurements; $L$, length; $W$, width; sin, sinistral; and dext, dextral. Abbreviations and terminology used in the description of the microstructure of enamel are as follows: HSB is the Hunter-Schreger band, IPM is the interprismatic matrix, PE is the portio externa, PI is the portio interna, IPI is the internal part of the PI and OPI is the external part of the PI. The terminology used in the description of the dental elements of the Gliridae is after Daams and de Bruijn (1995) of the Eomyidae and Dipodidae after Freudenthal and Martín-Suárez (2017) and of the Muridae and Spalacidae after Mein and Freudenthal (1971).

\section{Systematic palaeontology}

In the "Systematic palaeontology" section, the fossil rodents collected in Ugljevik and Paragovo are described. The distribution of fossils in the two sites is shown in Fig. 7, together with the early Oligocene fauna of Raljin-B in southern Serbia (Wessels et al. 2019) and the late Oligocene fauna of nearby Banovići (de Bruijn et al. 2013); all sites are shown on the map of Fig. 1.

Order Rodentia Bowdich, 1821

Suborder Eusciurida Flynn, Jacobs, Kimura and Lindsay, 2019

Family Gliridae Muirhead, 1819

For the classification of the Gliridae at the subfamily level, we follow Daams and de Bruijn (1995).

Subfamily Bransatoglirinae Daams and de Bruijn, 1995

Genus Bransatoglis Hugueney, 1967

(including Oligodyromys Bahlo, 1975; Paraglis Baudelot, 1970 and Butseloglis Vianey-Liaud, 1994). See Berger (2008).

Type species: Bransatoglis concavidens Hugueney, 1967

Bransatoglis cf. complicatus Ünay, 1994

(Fig. 8a-d, i-l, Fig. 9)

Locality: Ugljevik (UGL05)

Material: P4: no. 451, 454; M1-2: no. 453, 455, (456); M3: no. 457, (458); p4: no. 441; m1-2: no. 442-445, (446); m3 no. (447). Damaged specimens are between brackets.

Measurements: see Table 1 


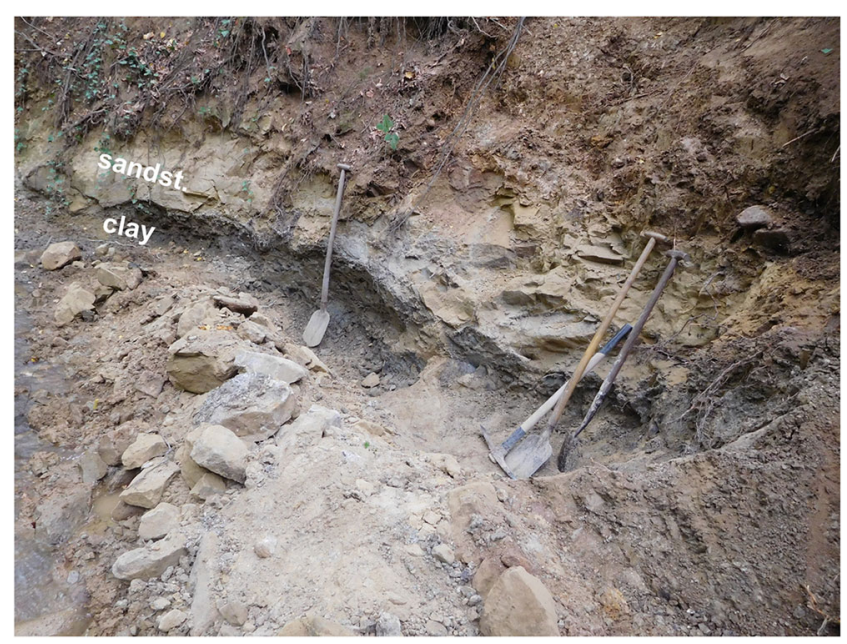

Fig. 5 The Paragovo site in 2017 after extensive sampling

\section{Description}

The occlusal surface of the cheek teeth is concave and the endoloph of the upper cheek teeth is complete.

P4: There is no interdental facet on the anterior side, so there was no P3. The occlusal surface of the P4 shows two centrolophs. The anterior one is long and reaches almost to the endoloph. There is an extra ridge between the anterior centroloph and the protoloph, between the anteroloph and the protoloph and between the metaloph and the posteroloph. M1: The centrolophs are long; in one M1, the anterior centroloph is connected to the endoloph; in the other, it is not. Low extra ridges outside the trigone are present between the anteroloph and the protoloph as well as between the posteroloph and the metaloph. Inside the trigone is an irregular ridge between the protoloph and the anterior centroloph; another irregular ridge is present between the posterior centroloph and the metaloph.
M2: The dental pattern of the M2 is even more complex than that of the M1 in showing four extra ridges inside the trigone; two between the protoloph and the anterior centroloph and two between the metaloph and the posterior centroloph.

M3: The anterior centroloph of the M3 is shorter than the posterior one which almost reaches the endoloph. Apart from the shorter posterior centroloph and posteriorly directed metaloph the pattern of the M3 is very similar to that of the $\mathrm{M} 2$.

p4: The anterolophid and metalophid enclose an oval valley containing a short extra ridge. The long centrolophid reaches almost to the labial border of the occlusal surface. The valley between the mesolophid, which shows an interruption in the middle, and posterolophid contains a well-developed extra ridge. m1: The dental pattern of the damaged and rather worn $\mathrm{m} 1$ is difficult to read. The anterior extra ridge and the centrolophid seem to be very long, while the valley between the mesolophid and the posterolophid contains two extra ridges. m2: The anterior extra ridge and the centrolophid are long, and there is a short extra ridge between the metalophid and the centrolophid. The valley between the mesolophid and the posterolophid contains two extra ridges. The anterior one of these is much longer than the posterior one.

m3: With the exception of an even longer centrolophid that reaches to the labial border of the occlusal surface, the occlusal pattern of the incomplete $\mathrm{m} 3$ seems to be the same as that of the $\mathrm{m} 2$.

\section{Microstructure of the lower incisor (Fig. 9)}

The external surface of the lower incisor lower incisor of Bransatoglis cf. complicatus from Ugljevik is smooth. Enamel thickness $\sim 30 \mu$. The transverse uniserial HunterSchreger bands (HSB) of the portio interna (PI) make an angle of about 10 degrees with the normal on the enamel-dentine

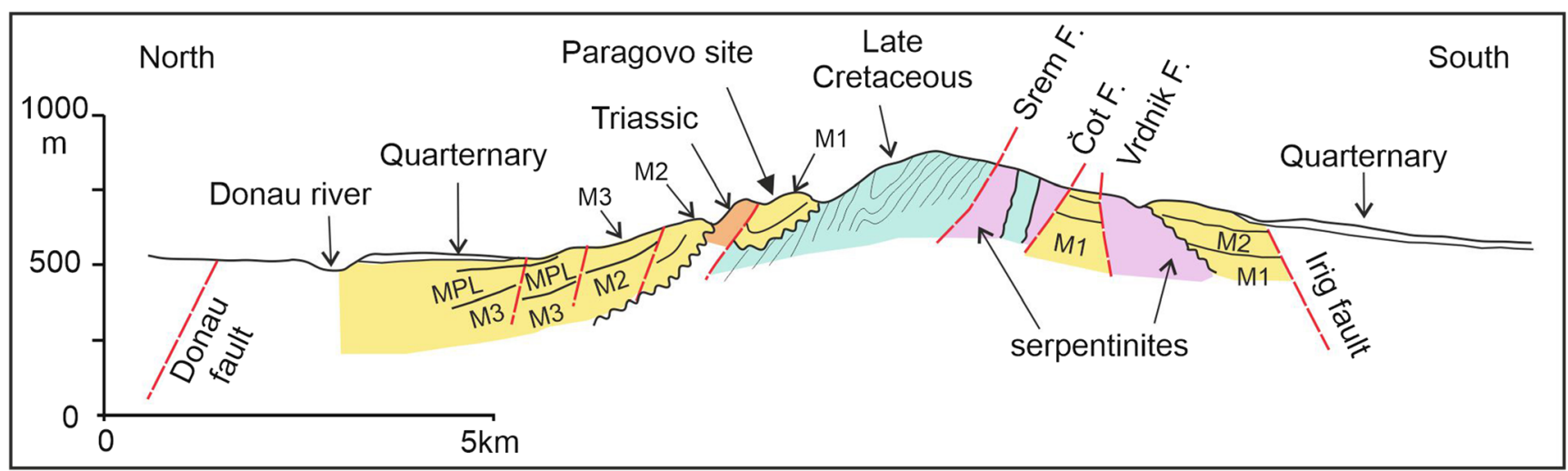

Fig. 6 Schematic cross section through the tectonic uplift of the Fruška Gora showing the location of the Paragovo site. M1-2, M2 and MPL map units of Čičulić and Rakić (1976, 1977); M1, Oligocene; M2 and M3, Miocene; MPL, Mio-Pliocene; F, fault. Modified after Petković et al. (1976) 


\begin{tabular}{|c|c|c|c|c|c|c|}
\hline \multirow[b]{2}{*}{ Family / Order } & \multirow[b]{2}{*}{ Subfamily } & & \multirow{2}{*}{$\begin{array}{c}\begin{array}{c}\text { Early } \\
\text { Oligocene }\end{array} \\
\text { Raljin-B } \\
\end{array}$} & \multicolumn{3}{|c|}{ Late Oligocene } \\
\hline & & & & Ugljevik & Paragovo & Banovići \\
\hline Diatomyidae & Diatomyinae & Inopinatia balkanica & 23 & & & \\
\hline \multirow{19}{*}{ Muridae } & \multirow{3}{*}{$\begin{array}{l}\text { Pseudo- } \\
\text { cricetodontinae }\end{array}$} & Heterocricetodon serbicus & 29 & & & \\
\hline & & Pseudocricetodon cf. montalbanensis & 51 & & & \\
\hline & & Pseudocricetodon cf. heissigi & 19 & & & \\
\hline & \multirow{2}{*}{ Paracricetodontinae } & Paracricetodon stojanovici & 42 & & & \\
\hline & & Paracricetodon dehmi & 3 & & & \\
\hline & \multirow{3}{*}{ Melissiodontinae } & Mogilia lautus & 17 & & & \\
\hline & & Mogilia sp. & 1 & & & \\
\hline & & Edirnella sp. & 3 & & & \\
\hline & Pappocricetodontinae & Witenia cf. flava & 4 & & & \\
\hline & Eucricetodontinae & Eucricetodon sp. & & 8 & & \\
\hline & \multirow{4}{*}{ Cricetodontinae } & cf. Deperetomys *1 & 1 & & & \\
\hline & & Deperetomys calefactus & & 205 & & \\
\hline & & Deperetomys saltensis & & & 17 & \\
\hline & & Deperetomys magnus & & & 5 & 15 \\
\hline & \multirow{5}{*}{ Eumyarioninae } & Eumyarion cf. microps & & & 13 & \\
\hline & & Eumyarion cf. margueritae & & & 5 & \\
\hline & & Eumyarion microps & & & & 70 \\
\hline & & Eumyarion margueritae & & & & 37 \\
\hline & & Mirrabella aff. anatolica & & & & 10 \\
\hline \multirow{2}{*}{ Spalacidae } & & Pannoniamys paragovensis $\mathrm{n}$. gen. $\mathrm{n} . \mathrm{sp}$. & & & 7 & \\
\hline & & Vetusspalax progressus & & & & 25 \\
\hline \multirow{2}{*}{ Dipodidae } & & Heosminthus primiveris & 26 & & & \\
\hline & & Plesiosminthus cf. schaubi & & & 4 & \\
\hline \multirow{5}{*}{ Gliridae } & \multirow{3}{*}{ Bransatoglirinae } & Bransatoglis cf. complicatus & & 9 & & \\
\hline & & Bransatoglis fugax & & & & 10 \\
\hline & & Bransatoglis bosniensis & & & & 9 \\
\hline & Dryomyinae & Microdyromys praemurinus *2 & & & 3 & 21 \\
\hline & & Gliridae gen. et sp. indet. & & & $x$ & \\
\hline \multirow{2}{*}{ Sciuridae } & & Palaeosciurus aff. feignouxi & & & & 6 \\
\hline & & Dehmisciurus obstusidens *3 & & & & $x$ \\
\hline Hystricognathi & Baluchimyinae & cf. Daxneria & & 1 & & \\
\hline Eomyidae & & cf. Eomys sp. indet. & & $x$ & & \\
\hline Lagomorpha & & gen. et sp. indet. * 4 & & & $\mathrm{X}$ & $x$ \\
\hline
\end{tabular}

Fig. 7 Distribution of rodent species in the early Oligocene assemblage of Raljin-B (Wessels et al. 2020) and the late Oligocene assemblages of Ugljevik, Paragovo (this paper) and Banovići (de Bruijn et al. 2013). Numbers refer to first and second molars, $\mathrm{X}$ indicates the presence of

junction (EDJ). The inter-prismatic matrix (IPM) in the PI is parallel to the prisms. The thin portio externa (PE) of $\sim 25 \%$, consists of radial enamel. This primitive enamel occurs in group 1 of von Koenigswald (1993, 1995). premolar or third molars. Notes: $* 1$ cf. Deperetomys sp. from Raljin, just below Raljin-B, see Marković et al. 2020; *2 Microdyromys monspeliensis in de Bruijn et al. 2013; *3 ?Ratufa obstusidens in de Bruijn et al. 2013;*4 new Lagomorpha gen. et sp. indet

\section{Comments on Bransatoglis}

Since the studies by von Koenigswald (1993, 1995), new information on the incisor microstructure of the Gliridae 
has not been published. The difficulty of correctly combining incisors with cheek teeth in assemblages of isolated molars is probably the main reason for this. Because incisors and cheek teeth have been found associated, the microstructure of our Bransatoglis from Ugljevik can be confidently elucidated. Von Koenigswald recognised three groups of glirids: group 1 with transverse HSB, group 2 with diagonal HSB and group 3 with longitudinal HSB. Oligocene Bransatoglis from Ugljevik, with its primitive enamel, can be added to group 1. Von Koenigswald (1995) included in group 1 Oligocene Gliravus sp., extant Glis glis and extant Glirulus japonicus. Von Koenigswald left the question open of the significance of microstructure types for the recognition of clades. Combining the results of von Koenigswald with the classification of the Gliridae (Daams and de Bruijn 1995) suggest that the enamel types of groups 2 and 3 are plesiomorphic, that is, occurring independently in the different subfamilies.

The few Bransatoglis cheek teeth from Ugljevik belong to the medium-sized group of species which were allocated to the genus Paraglis Baudelot, 1970 by Freudenthal and Martín-Suárez (2007a, figs. 4, 5). The size and overall dental pattern of the teeth from Ugljevik is very similar to that of B. mojai (Hugueney and Adrover, 1989-1990) from the late Oligocene of Sineu (Balearic Islands) and of B. complicatus Ünay, 1994 from the early Miocene of Harami 1 (Central Anatolia). The dental pattern of the specimens from Ugljevik is somewhat more complex than in the teeth from Sineu and Harami 1, but is expected to be within the unknown range of variation of either species if larger samples would be available. The similarity of the teeth from these three localities is striking despite the large distances between these occurrences. Differences are limited to the length of the anterior centroloph in the M1-2 and the number of extra ridges within the trigone. Unfortunately, the material available from all three localities is very limited, so taxonomical evaluation of these minor differences is impossible for the time being. It is therefore conceivable that larger samples would lead to the conclusion that we are dealing with either one, two or even three different species. Our allocation to Bransatoglis cf. complicatus is thus preliminary.

Subfamily Dryomyinae de Bruijn, 1967

Genus Microdyromys de Bruijn, 1966

Type species: M. koenigswaldi de Bruijn, 1966

Microdyromys praemurinus (Freudenberg, 1941)

(Figure 10a-f)

Type locality: Gaimersheim (Germany)

Locality: Paragovo (PAR015)

Material: P4: no. 221-222; M1-2: no 223; M3: no. 225-226; p4: no.231-233; m1: no. 234-235; m3: no. 236-240.
Measurements: see Table 2

\section{Description}

P4: The occlusal surface of the, relative to the M1, rather large P4 is oval. The anteroloph is well-developed. The protoloph and metaloph reach the lingual side separately. The anterior centroloph is long, but the posterior centroloph is vestigial. The long posteroloph connects the protocone with the metacone.

M1-2: The anterior side of the only M1-2 available from Paragovo is slightly narrower than the posterior side, so this tooth is probably a M1. The long protoloph connects the protocone and the paracone. The protoloph and the metaloph converge towards the protocone. The anterior centroloph is long, but ends free lingually. There is a short extra ridge between the protoloph and the anterior centroloph. The posterior centroloph and the metaloph are not attached to the metacone which is incorporated into the strong posteroloph.

M3: The long anteroloph and protoloph are parallel ridges connecting the protocone to the paracone. There is an anterior extra ridge between the long anterior centroloph and the protoloph in both specimens, but the pattern of the posterior parts of these teeth is rather different because the lingual end of the figured specimen is fused to the lingual part of the metaloph. This is not the case in the other specimen, which has a short metaloph and posterior centroloph separate from the anterior centroloph.

p4: The anterolophid and the metalophid form one oval ridge. The centrolophid is rather long and there is an extra ridge within the loupe formed by the mesolophid and posterolophid. m1: The anterolophid and metalopid form a continuous ridge enclosing a valley containing an anterior extra ridge. The long centrolophid is not connected to the metaconid. There is a posterior extra ridge in the valley formed by the mesolophid and the posterolophid.

m3: The size and dental pattern among the five $\mathrm{m} 3$ shows considerable individual variation, but all share the four main ridges, a centrolophid and the presence of an anterior and a posterior extra ridge.

\section{Discussion}

We do not follow Freudenthal and Martín-Suárez (2007a) who suggest to transfer Microdyromys to the Bransatoglirinae. The few Microdyromys specimens available from Paragovo seem to represent the same species as in Banovići, which was described earlier as Microdyromys cf. monspeliensis Aguilar, 1977 (de Bruijn et al., 2013, plate 2, figs. 13-24). The study of the Paragovo material resulted in a revision of our earlier identification. We now consider the Banovići as well as the Paragovo material to represent M. praemurinus.

The cheek teeth of the small glirid from Paragovo and Banovići are morphologically within the range of 


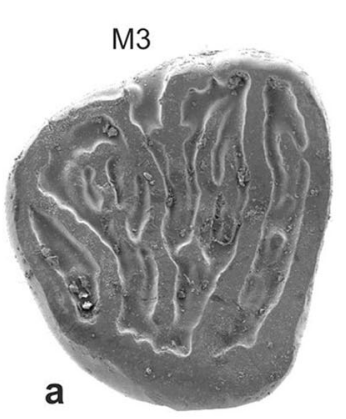

$\underline{b}$
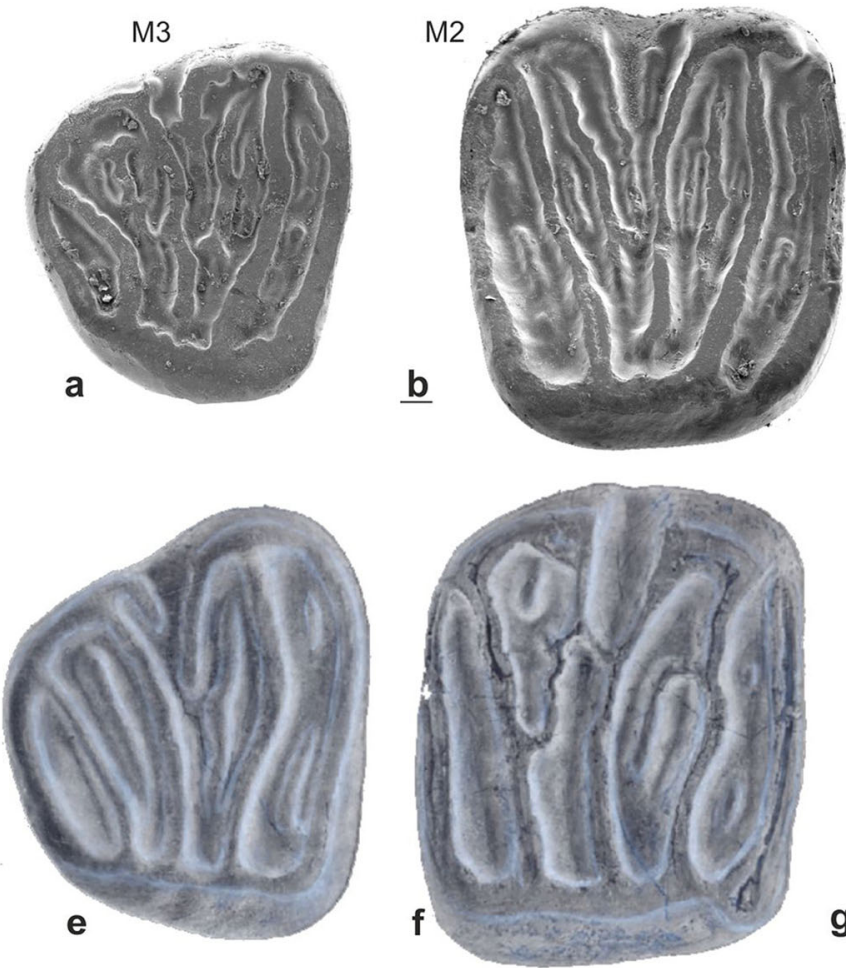

g

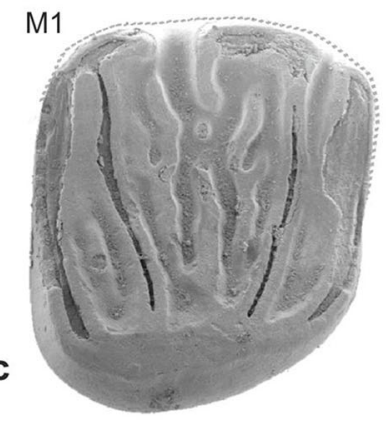

\section{d}
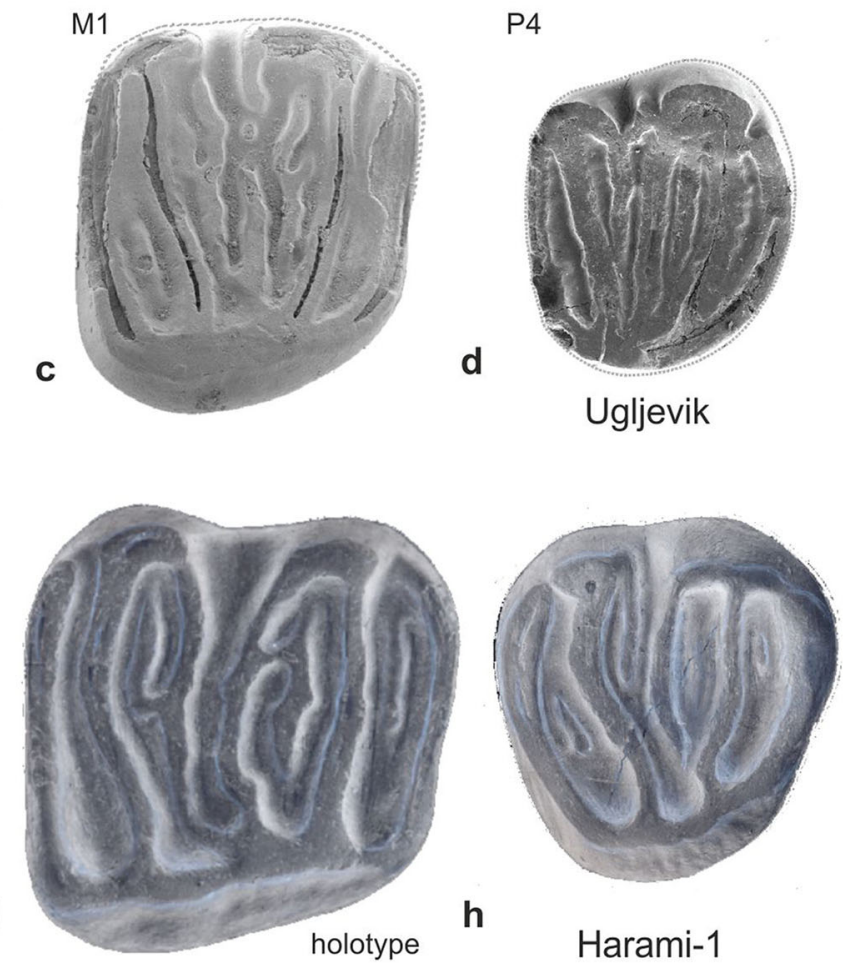

h

Harami-1

p4
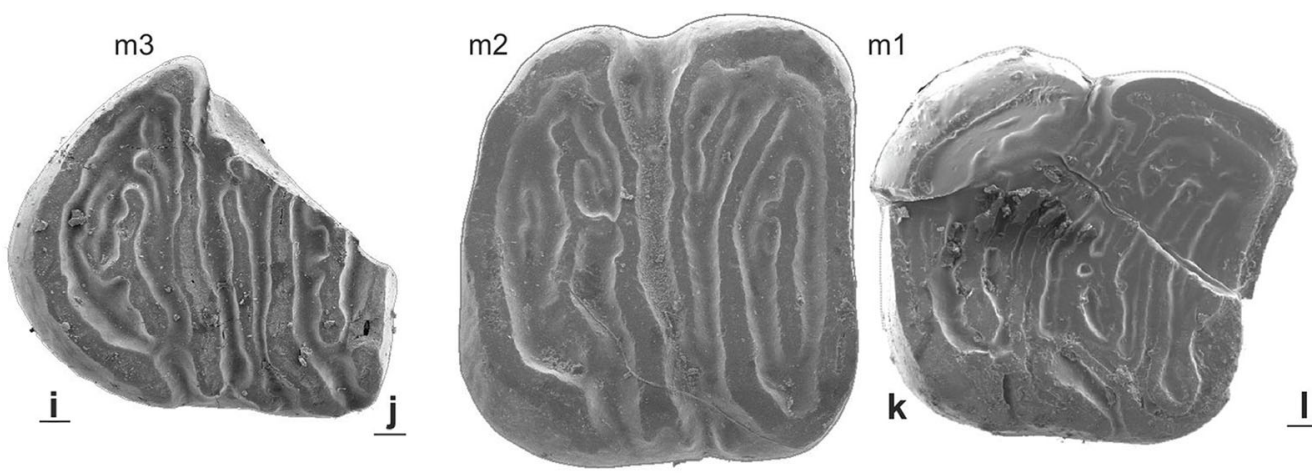

I
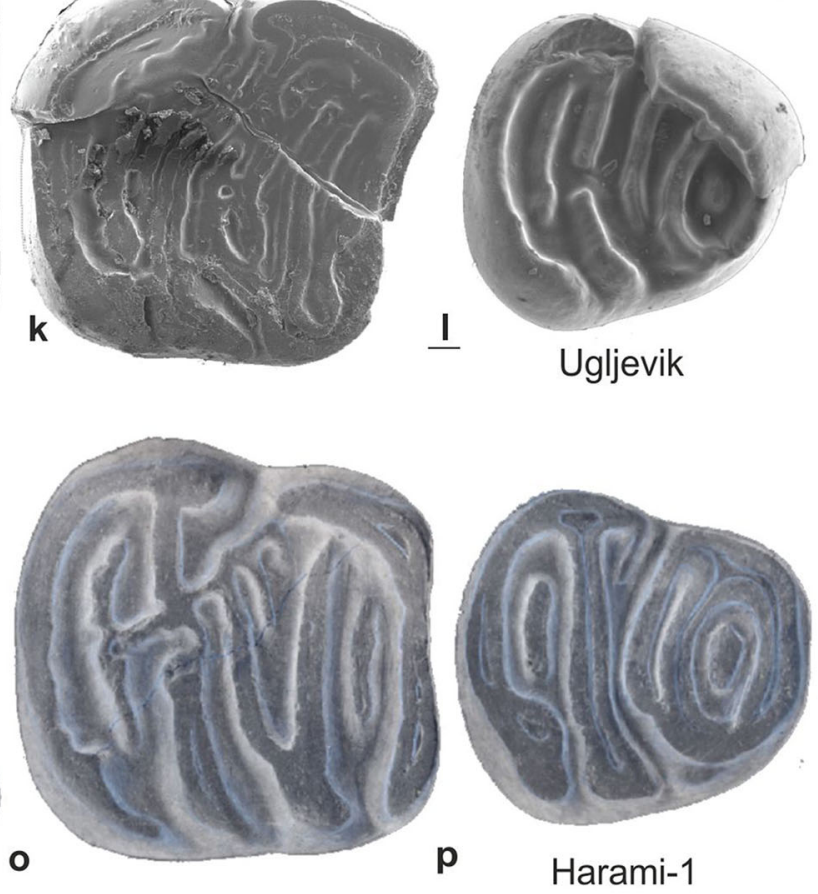

Ünay, 1994). a UGL450. b UGL454. c UGL453. d UGL460. i UGL447. j UGL442. k UGL444. I UGL441. Collection numbers of the Harami specimens are not available

Ugljevik and Bransatoglis complicatus (e-h) from the type loct Harami-1. Lower dentition of $B$ cf complicatus (i-l) from Ugljevik and $B$. complicatus $(\mathbf{m}-\mathbf{p})$ from the type locality Harami-1 (see

Microdyromys praemurinus from the type locality Gaimersheim (Kristkoiz, 1992). The material from Banovići is on average somewhat larger than that from Gaimersheim, but overlaps. In contrast to the situation in the geologically older Microdyromys 


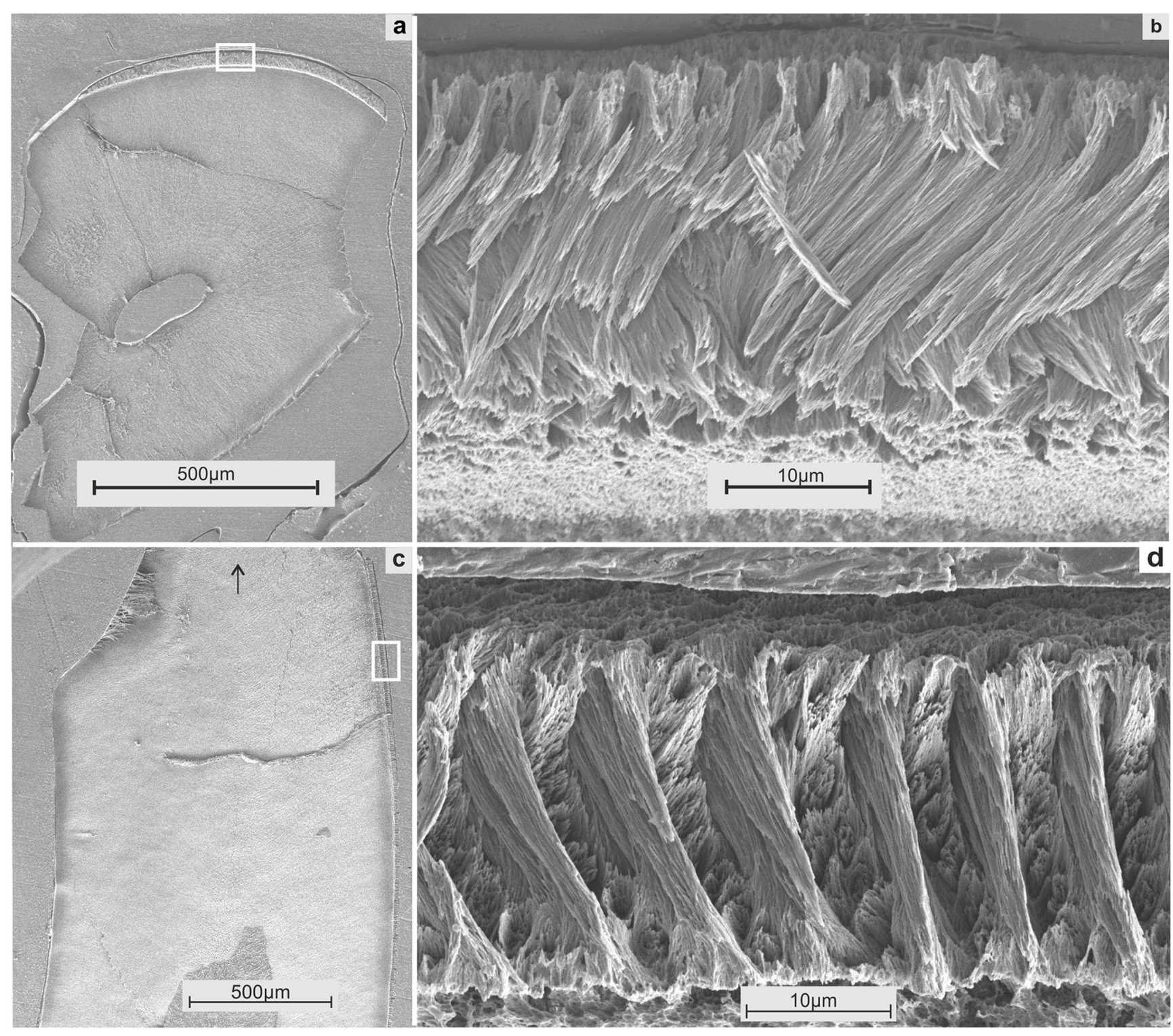

Fig. 9 Sections of the lower incisor of Bransatoglis cf. complicatus from Ugljevik. a Transverse section. b Enlargement of square in a. c Sagittal section, upper arrow indicates top. $\mathbf{d}$ Enlargement of square in $\mathbf{c}$

misonnei, M. antiquus, $M$. puntarronensis and M. heissigi, the endoloph of the M1-M2 is complete and the labial end of the anterolophid of the $\mathrm{m} 1-\mathrm{m} 2$ is connected to the protoconid, which is the morphology seen in early Miocene Microdyromys samples. Metrically, these teeth are closer to the material from the type locality of M. praemurinus than to those of M. monspeliensis (Table 2). It is of interest that the detachment of the posterior centroloph from the metacone in the M1-2 and of the centrolophid from the metaconid in the $\mathrm{m} 1$ occurs in the Bosnian as well as in the Serbian association. This feature supports our conclusion that the same species is present in both localities.

Gliridae gen. et sp. indet.

(Fig. 10h)

Locality: Paragovo (PAR015)
Material and measurement: $1 \mathrm{p} 4$, no. 241 , length $\mathrm{x}$ width $0.93 \times 0.89 \mathrm{~mm}$.

\section{Remarks}

This worn $\mathrm{p} 4$ is much too large to be included into the variation of Microdyromys cf. praemurinus. Although its dental pattern is difficult to read, it seems that there is (or has been) an anterior as well as a posterior extra ridge. Its size is within the range of Bransatoglis fugax (Hugueney 1967), while the shape of its occlusal surface is reminiscent of the $\mathrm{p} 4$ of that species. Taking into account that the rodent association from Paragovo shares a number of species with that from Banovići, a locality that contains Bransatoglis fugax, there is a fair chance that this unidentifiable tooth represents this species. 
Table 1 Measurements of Bransatoglis cf. complicatus from Ugljevik. Measurements of Bransatoglis mojai (Hugueney and Adrover, 19891990) from Sineu and Bransatoglis complicatus Ünay, 1994 from Harami-1 have been added for comparison

\begin{tabular}{|c|c|c|c|c|c|c|c|c|}
\hline & \multicolumn{4}{|l|}{ Length } & \multicolumn{4}{|l|}{ Width } \\
\hline & Range & Average & $\mathrm{N}$ & SD & Range & Average & $\mathrm{N}$ & $\mathrm{SD}$ \\
\hline \multicolumn{9}{|c|}{ Ugljevik } \\
\hline P4 & $0.94-0.97$ & 0.955 & 2 & 0.021 & $1.07-1.18$ & 1.115 & 2 & 0.078 \\
\hline M1-2 & $1.05-1.22$ & 1.157 & 3 & 0.093 & $1.20-1.36$ & 1.283 & 3 & 0.071 \\
\hline M3 & $1.00-1.10$ & 1.050 & 2 & 0.071 & 1.150 & 1.150 & 1 & - \\
\hline $\mathrm{p} 4$ & - & 0.960 & 1 & - & - & 0.950 & 1 & - \\
\hline $\mathrm{m} 1-2$ & $1.15-1.24$ & 1.208 & 4 & 0.043 & $1.25-1.35$ & 1.293 & 4 & 0.043 \\
\hline $\mathrm{m} 3$ & - & 1.230 & 1 & - & - & - & - & - \\
\hline \multicolumn{9}{|l|}{ Sineu } \\
\hline P4 & - & 1.010 & 1 & - & - & 1.160 & 1 & - \\
\hline M2 & - & 1.140 & 1 & - & - & 1.440 & 1 & - \\
\hline $\mathrm{p} 4$ & - & 1.080 & 1 & - & - & 0.960 & 1 & - \\
\hline $\mathrm{m} 2$ & $1.25-1.30$ & 1.275 & 2 & - & $1.33-1.44$ & 1.370 & 2 & - \\
\hline \multicolumn{9}{|c|}{ Harami 1} \\
\hline P4 & - & 1.060 & 1 & - & - & 1.150 & 1 & - \\
\hline M2 & - & 1.180 & 1 & - & - & 1.440 & 1 & - \\
\hline $\mathrm{p} 4$ & - & 1.060 & 1 & - & - & 1.010 & 1 & - \\
\hline $\mathrm{m} 2$ & - & 1.450 & 1 & - & - & 1.500 & 1 & - \\
\hline
\end{tabular}

Suborder Supramyomorpha D'Elia, Fabre et Lessa, 2019

Family Eomyidae Déperet and Douxami, 1902

Genus Eomys Schlosser, 1884

cf. Eomys sp.

(Fig. 10g)

Locality: Ugljevik (UGL05)

Material and measurements: $1 \mathrm{p} 4$ sin. no. 461, length $\mathrm{x}$ width: $0.95 \times 0.79 \mathrm{~mm}$.

\section{Description}

This $\mathrm{p} 4$ from Ugljevik has a minute anteroconid, a weak mesolophid that does not reach the lingual border of the occlusal surface and a well-developed fourth lingual synclinid. Rather unusual for an Eomys p4 is the relatively welldeveloped mesoconid.

\section{Remarks}

The small low-crowned eomyid $\mathrm{p} 4$ collected from the Ugljevik coal in 2005 seems to represent the genus Eomys; it resembles the p4 of Eomys sp. A from Kocayarma, (middle Oligocene of the Thrace basin, Ünay-Bayraktar, 1989), of Eomyodon volkeri Engesser, 1987 and Eomys molassicus
Engesser 1987 (both late Oligocene Switzerland). Since the morphology of the p4 of the type species of Eomys (E. zitteli Schlosser, 1884) and of the type species of Eomyodon (E. volkeri Engesser, 1987) is virtually identical, the generic assignment of our tooth remains uncertain. There is in fact some doubt whether Eomys and Eomyodon are discrete generic entities, a discussion that is beyond the scope of this paper. Eomys is absent in the early Oligocene assemblages of southern Serbia, present in two "middle" Oligocene assemblages of the Thrace basin (Ünay-Bayraktar, 1989) and the late Oligocene of Ugljevik but absent in the latest Oligocene faunas from Banovići and Paragovo.

Infraorder Myodonta Schaub, 1958

Family Dipodidae Fischer, 1817

Since grouping of the primordial Paleogene genera of the Dipodidae into subfamilies is very controversial, we refrain from allocating Plesiosminthus to subfamily.

Genus Plesiosminthus Viret, 1926

Type species: Plesiosminthus schaubi Viret, 1926

Introduction

Dipodidae and Muridae are generally considered to be sister groups of Asian origin. The so far oldest record of a dipodid from Europe is Heosminthus primiveris Wang, 1985 from the early Oligocene sites Valniš, Strelac 3 and Raljin (S.E. Serbia; Wessels et al. 2020). Since Heosminthus is not known from elsewhere in Europe, we assume that this Asian genus did not reach westward and northwards beyond the Balkans. The second migration of a dipodid from Asia into Europe is documented by Plesiosminthus moniqueae Freudenthal and Martin-Suárez, 2017 from the late Oligocene site Mirambueno 1 (MP 27), Spain. In sharp contrast to Central Asia, the Dipodidae never became a diverse and dominant constituent of European Paleogene rodent associations. The European members of Plesiosminthus were recently revised by Freudenthal and Martín-Suárez (2017). These authors recognise, next to the inadequately documented $P$. promyarion Schaub, 1930 (a name that Freudenthal and Martin-Suárez suggest to restrict to its poor type material), nine species.

The excellent documentation provided by Freudenthal and Martín-Suárez (2017) shows that Plesiosminthus has a stratigraphical range in Europe from MP27-MN2, which is roughly 5-6 million years. All studied samples overlap in size as well as in dental characteristics, while there appears to be neither a stratigraphical nor a geographical polarity in these characteristics. The study by Freudenthal and Martín-Suárez (2017) thus reveals the mosaic history of the group, which makes the status of the majority of the nine formally defined European Plesiosminthus "species" uncertain, that is, the genus is oversplit. The species concept suggested by Freudenthal and Martin-Suárez makes the identification of small samples 
Table 2 Measurements of Microdyromys praemurinus from Paragovo. Measurements of $M$. praemurinus from the type locality Gaimersheim (Kristkoiz, 1992), M. praemurinus from Banovići (de Bruijn et al., 2013) and M. monspeliensis from the typelocality Nouvelle Faculté de Médicine (Aguilar, 1977) have been added for comparison

\begin{tabular}{|c|c|c|c|c|c|c|c|c|}
\hline \multirow[t]{2}{*}{ Microdyromys } & \multicolumn{4}{|l|}{ Length } & \multicolumn{4}{|l|}{ Width } \\
\hline & Range & Mean & $\mathrm{N}$ & $\mathrm{SD}$ & Range & Mean & $\mathrm{N}$ & $\mathrm{SD}$ \\
\hline \multicolumn{9}{|l|}{ Paragovo } \\
\hline P4 & $0.64-0.65$ & 0.650 & 2 & --- & $0.65-0.80$ & 0.780 & 2 & --- \\
\hline M1-2 & --- & 0.860 & 1 & --. & - & 0.910 & 1 & --- \\
\hline M3 & $0.66-0.68$ & 0.670 & 2 & -- & $0.73-0.83$ & 0.780 & 2 & --- \\
\hline $\mathrm{p} 4$ & $0.60-0.63$ & 0.620 & 3 & 0.015 & $0.55-0.58$ & 0.560 & 3 & 0.017 \\
\hline $\mathrm{m} 1$ & $0.90-0.91$ & 0.910 & 2 & --- & $0.81-0.86$ & 0.840 & 2 & --- \\
\hline $\mathrm{m} 3$ & $0.81-0.88$ & 0.850 & 5 & 0.036 & $0.65-0.80$ & 0.740 & 5 & 0.058 \\
\hline \multicolumn{9}{|l|}{ Gaimersheim } \\
\hline M1-2 & $0.74-0.88$ & --- & 20 & --- & $0.75-0.99$ & --- & 20 & --- \\
\hline M3 & $0.64-0.75$ & --- & 2 & --- & $0.75-0.89$ & --- & 2 & --- \\
\hline $\mathrm{m} 1$ & $0.71-0.89$ & --- & 19 & --- & $0.60-0.85$ & --- & 19 & --- \\
\hline $\mathrm{m} 2$ & $0.67-0.90$ & --- & 16 & --- & $0.70-0.89$ & --- & 16 & --- \\
\hline $\mathrm{m} 3$ & --- & --- & --- & --- & --- & 0.700 & 1 & --- \\
\hline \multicolumn{9}{|l|}{ Banovići } \\
\hline P4 & --. & 0.580 & 1 & -.- & --- & 0.840 & 1 & --- \\
\hline M1-2 & $0.83-0.95$ & 0.880 & 10 & 0.035 & $0.93-1.12$ & 1.022 & 10 & 0.060 \\
\hline M3 sup & $0.71-0.76$ & 0.735 & 2 & --- & $0.89-0.96$ & 0.925 & 2 & --- \\
\hline $\mathrm{p} 4$ & $0.63-0.74$ & 0.673 & 3 & 0.059 & $0.59-0.72$ & 0.643 & 3 & 0.068 \\
\hline $\mathrm{m} 1-2$ & $0.85-1.05$ & 0.947 & 11 & 0.055 & $0.86-1.02$ & 0.948 & 11 & 0.057 \\
\hline $\mathrm{m} 3$ & --- & 0.910 & 1 & --- & --- & 0.840 & 1 & --- \\
\hline \multicolumn{9}{|l|}{ Nouv. Fac. Med. } \\
\hline M1-2 & $0.67-0.76$ & --- & 2 & -- & $0.86-0.93$ & --- & 2 & --- \\
\hline M3 & --- & 0.610 & 1 & --- & --- & 0.730 & 1 & --- \\
\hline $\mathrm{m} 1$ & $0.74-0.78$ & --- & 3 & --- & $0.73-0.75$ & --- & 3 & --- \\
\hline $\mathrm{m} 2$ & $0.75-0.80$ & --- & 6 & --- & $0.80-0.88$ & --- & 6 & --- \\
\hline $\mathrm{m} 3$ & $0.70-0.77$ & --- & 4 & --- & $0.71-0.75$ & --- & 4 & -- \\
\hline
\end{tabular}

impossible, and new large samples are expected to have characteristics in between named species.

Plesiosminthus cf. schaubi Viret, 1926

(Figure 10i-l)

\section{Locality: Paragovo (PAR015)}

Material and measurements: M1: no. 211-212, (length $x$ width $1.13 \times 1.07 \mathrm{~mm}, 1.25 \times 1.15 \mathrm{~mm}$ ); M2: no. (213), (length $1.18 \mathrm{~mm})$; m1: no. $216(1.25 \times 1.00 \mathrm{~mm})$; two fragments of upper incisors with a sulcus. Specimen numbers between brackets indicate that these are damaged.

\section{Description}

M1: The long anteroloph connects the protocone to the base of the paracone. The protolophule is directed slightly posteriorly, but the metalophule is directed somewhat anteriorly and inserts on the anterior part of the hypocone. The long straight mesoloph reaches to the labial edge of the occlusal surface. The, relative to the anteroloph, short posteroloph connects the hypocone to the base of the metacone.
M2: The somewhat damaged M2 shows a single forwarddirected protolophule which is parallel to the metalophule. The mesoloph is long.

I: Upper incisor with sulcus.

m1: The isolated anteroconid is situated closer to the metaconid than to the protoconid. The metalophulid 1 is absent, while the metalophulid 2 is formed by the posterior arm of the protoconid. The longitudinal ridge is complete. The long mesolophid ends lingually in a weak mesostylid. The hypolophid inserts on the longitudinal ridge in front of the hypoconid. The posterolophid connects the hypoconid with the posterior spur of the entoconid.

Remarks

The four dipodid cheek teeth from Paragovo are allocated to the genus Plesiosminthus because the accompanying upper incisor shows the, for that genus characteristic, sulcus (Fig. 10i). The size of these specimens, in particular the length of the M2, fits the rather large MP30 species $P$. admyarion Comte2000, P. meridionales Comte2000 and P. winistoerferi Engesser 1987 better than it does the somewhat smaller older and younger species (see Freudenthal and Martin-Suárez 2017). Furthermore, the M2 from Paragovo shows a single forward-directed protolophule, which is the dominant morphotype in the samples of $P$. schaubi from Coderet and of the very similar, and possibly identical, $P$. admyarion from Thézels. We consequently allocate the few specimens from Paragovo to Plesiosminthus cf. schaubi.

Infraorder Myodonta Schaub, 1958

Family Muridae Illiger, 1811

Subfamily Cricetodontinae Schaub, 1925

Genera included Cricetodon Lartet, 1851, Deperetomys Mein and Freudenthal, 1971, Hispanomys Mein and Freudenthal, 1971, Byzantinia de Bruijn, 1976 and Gobicricetodon Qiu, 1996.

Genus Deperetomys Mein and Freudenthal, 1971

Type species: Deperetomys hagni (Fahlbusch, 1964)

Introduction

The genus was originally known by a single species from the middle Miocene of North Alpine foreland basins of Germany and Switzerland, see Prieto (2012) for a review. De Bruijn et al. $(1987,1993)$ extended its range to the early Miocene of Anatolia and de Bruijn et al. (2013) to the late Oligocene of Banovići (Bosnia and Herzegovina), and Marković et al. (2019) described two new Deperetomys species from Ugljevik and Paragovo (Fig. 11). One species, Deperetomys calefactus, has been found in Ugljevik and two species, D. magnus and D. saltensis, in Paragovo (Fig. 7). 


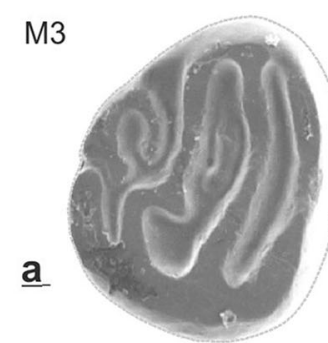

b
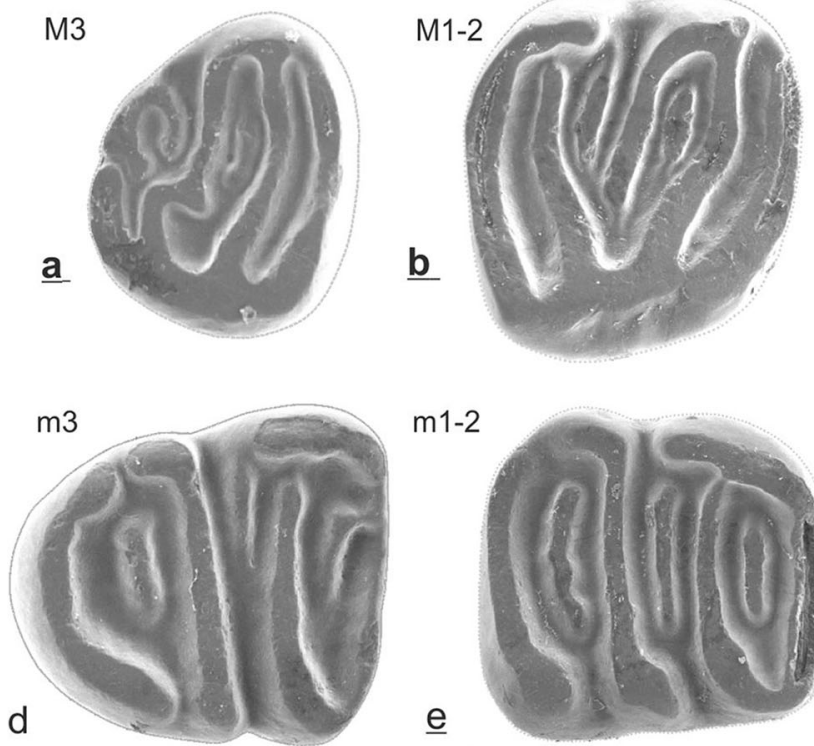

$0.5 \mathrm{~mm}$ $\mathrm{m} 1-2$

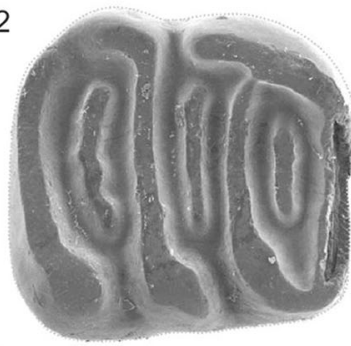

$\underline{e}$

Microdyromys praemurinus Paragovo
C

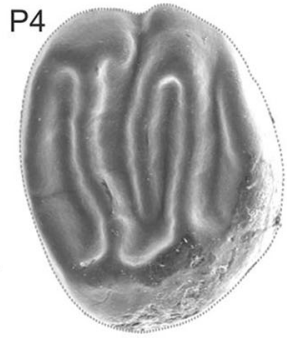

p4

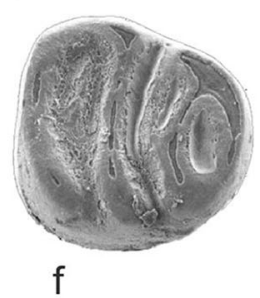

$\mathrm{f}$

p4

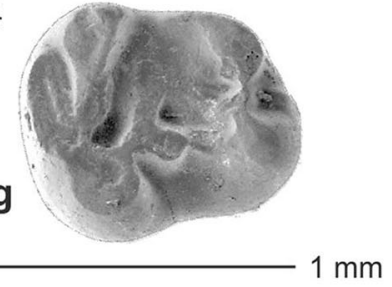

cf. Eomys sp. Uglevik

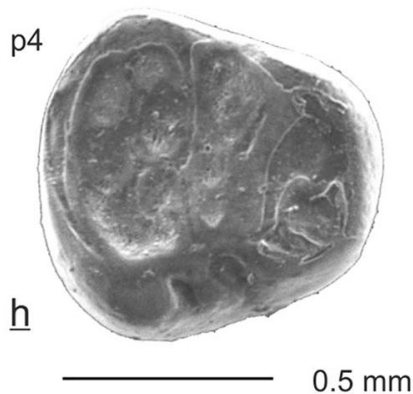

Gliridae gen. et sp. indet.

Paragovo

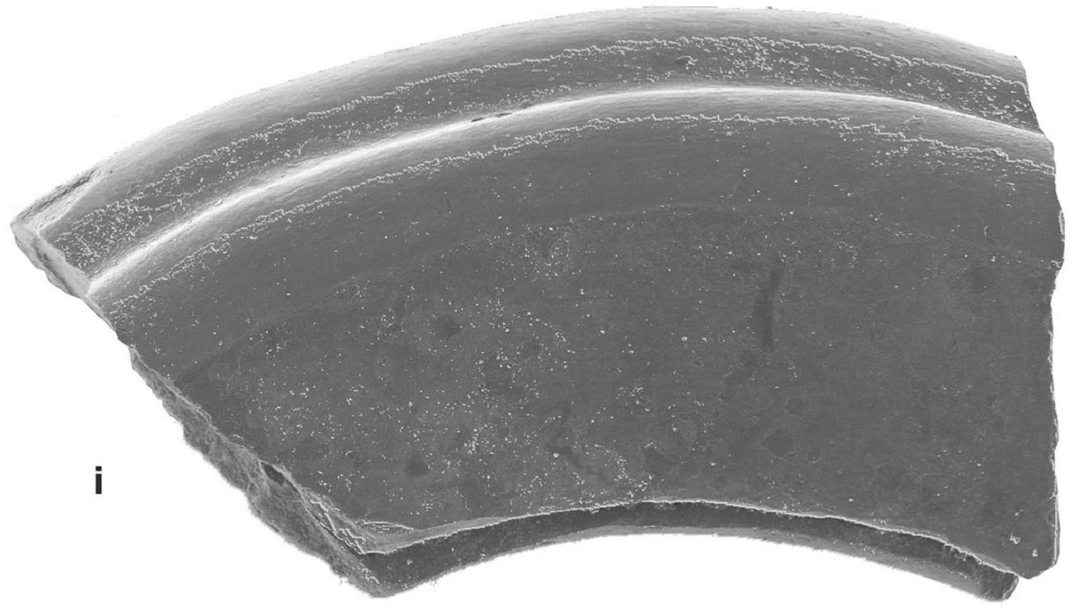

$0.5 \mathrm{~mm}$
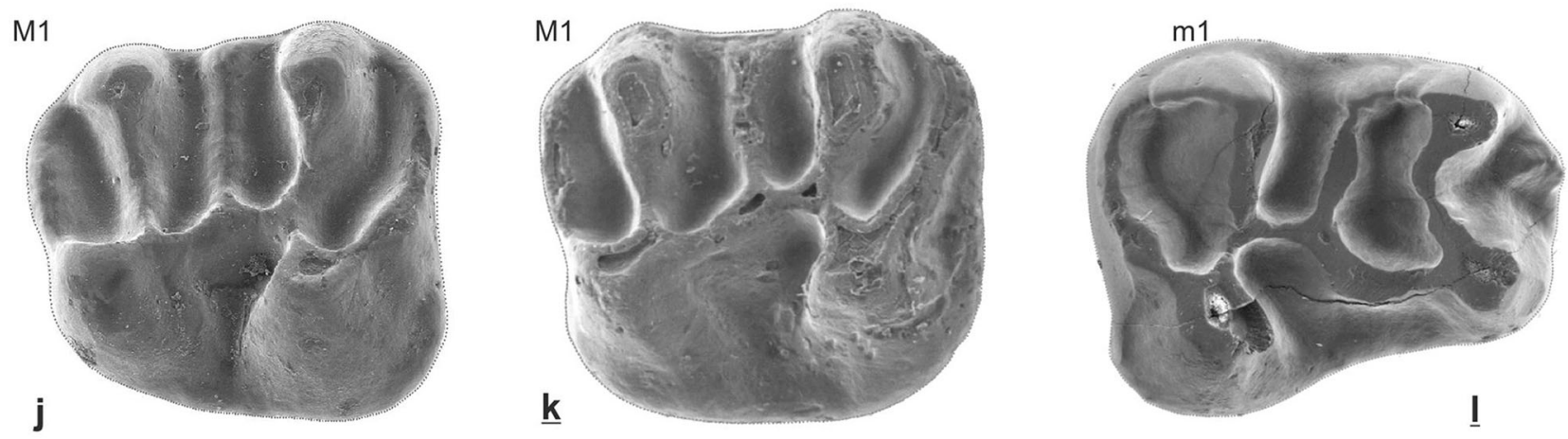

Plesiosminthus cf. schaubi Paragovo

Fig. 10 a-f Microdyromys praemurinus from Paragovo. $\mathrm{g} \mathrm{cf}$. Eomys sp. from Ugljevik. h Gliridae gen. et sp. indet. from Paragovo. i-I Plesiosminthus cf. schaubi from Paragovo. a PAR015 225. b PAR015
223. c PAR015 221. d PAR015 236. e PAR015 235. f PAR015 232. g UGL05 461. h PAR015 241. i PAR015 215. j 211. k PAR015 212. I PAR015 216 
Deperetomys calefactus Marković et al., 2019

(Figure 11g-1,p-r)

Locality: Ugljevik (UGL05)

Material and measurements: see Marković et al., 2019.

Deperetomys saltensis Marković et al., 2019

(Figure 11d-f, m-o)

Locality: Paragovo (PAR015)

Material and measurements: see Marković et al., 2019

Deperetomys magnus de Bruijn et al., 2013

(Figure 11a-c, j-1)

Locality: Paragovo (PAR015)

Material and measurements: see Marković et al., 2019

\section{Remarks}

For a recent description of the genus and a discussion of the species from Ugljevik and Paragovo, see Marković et al. (2019). Here, we limit the information to a short characterisation and figures of the cheek teeth. Deperetomys calefactus is relatively small, $D$. saltensis is similar in size and D. magnus is much larger (Fig. 12). D. magnus differs in morphology from $D$. saltensis in its less cuspate anteroconid, the stronger posterior arm of the protoconid, better-developed mesolophid of the $\mathrm{m} 1$ and the presence of a posterior arm of the hypoconid in the $\mathrm{m} 1$ and $\mathrm{m} 2$ (Fig. 12).

The M1 and M2 of D. calefactus differ from those of D. saltensis in having a free-ending anterior arm of the protocone, a much stronger posterior spur of the paracone, stronger mesolophs and transverse metalophs. The morphology of the $\mathrm{m} 1$ of $D$. calefactus differs from those of D. magnus in its less cuspate anteroconid, stronger posterior arm of the protoconid and the stronger mesolophid. The freeending anterior arm of the protocone in the M1 and M2 of D. calefactus is absent in these teeth of D. magnus. Moreover, the posterior spur of the paracone and the mesolophs of the M1 and M2 are much stronger while the metalophs are transverse in the smaller species, but posteriorly directed in D. saltensis and D. magnus.

Subfamily Eucricetodontinae Mein and Freudenthal, 1971 Genus Eucricetodon Mein and Freudenthal, 1971

Type species: E. collatus (Schaub, 1925)

\section{Eucricetodon sp.}

(Figures 13j-o, 14)

Locality: Ugljevik (UGL05)
Material: M1: no. 426, (432); M2: no. 428, (432); m1: no. 421, 431; m2 no. 422, 431; m3: nos. 423, 424, 431. Different teeth with same number are from one individual; damaged specimens between brackets.

Measurements: see Table 3

\section{Description}

M1: The anterocone is rather broad. It has a lingual spur that connects to the base of the protocone and a labial spur that connects to the base of the paracone. Although the anterocone is situated more or less on the longitudinal axis of the occlusal surface, it is set off lingually. The short anterior arm of the protocone and the somewhat longer anterior arm of the hypocone are parallel and directed forwards. The protoloph and metaloph are parallel, directed backwards and inserting lingually behind the protocone and the hypocone. The sinus is wide and only slightly directed forwards.

M2: The single unworn M2 available is damaged posteriorly. The valley between the anteroloph and the protoloph is shallow and narrow. The labial arm of the protoloph is much longer than the lingual arm. The short forwards directed protoloph inserts in front of the protocone. The anterior arm of the hypocone is short and does not reach the mesostyl. The sinus of the M2 is narrower and more forward-directed than in the M1.

$\mathbf{m 1}$ : The short anteroconid is situated very close to the metaconid, so the wear facets of these cusps fuse after moderate wear. The short posterior arms of the protoconid and hypoconid are parallel. The posterior arm of the protoconid is connected to the metaconid in both specimens. The posterior arm of the hypoconid ends free in one, and is connected to the entoconid in the other $\mathrm{m} 1$. The mesolophid is long. The short hypolophid inserts in front of the hypoconid. The sinusid is wide.

m2: The valley between the lingual branch of the anterolophid and the metalophid is very shallow. The parallel metalophid and hypolophid are short and insert in front of the protoconid and hypoconid. The posterior arm of the protoconid and the mesolophid are both short and end-free lingually. The posterior arm of the hypoconid is absent. The posterolophid reaches the base of the entoconid. The sinusid is wide and only weakly posteriorly directed.

$\mathbf{m 3}$ : The anterolophid of the $\mathrm{m} 3$ is stronger than in the $\mathrm{m} 2$. Its lingual and labial branch are about equal in length. The parallel metalophid and hypolophid are directed forwards and insert labially in front of the protoconid and hypoconid. The posterior arm of the protoconid is much stronger in the $\mathrm{m} 3$ than in the $\mathrm{m} 2$, and reaches almost to the entoconid in both unworn specimens. A free posterior arm of the hypoconid is absent. The posterolophid connects to the entoconid. The wide sinusid of the $\mathrm{m} 3$ is more posteriorly directed than in the $\mathrm{m} 2$. 

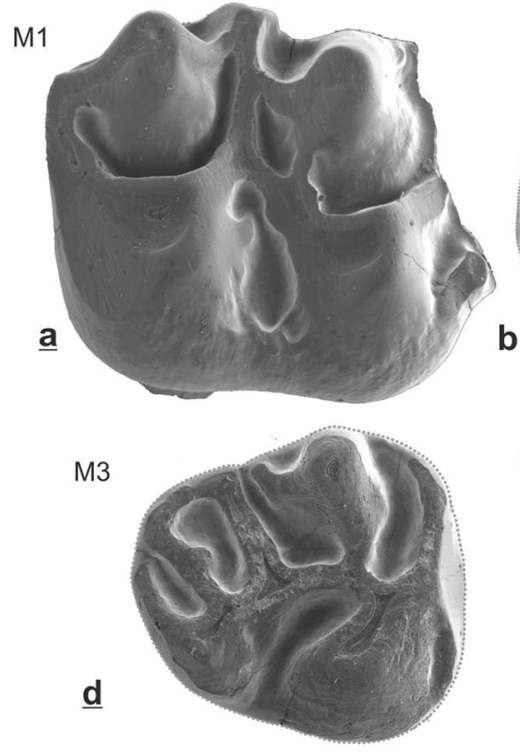

M3

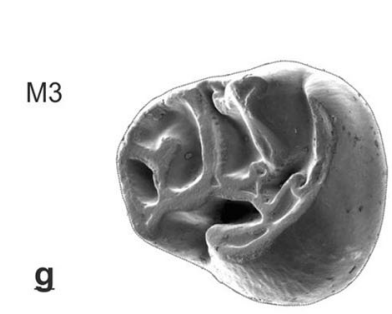

$\underline{\mathbf{h}}$

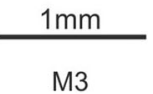

m3
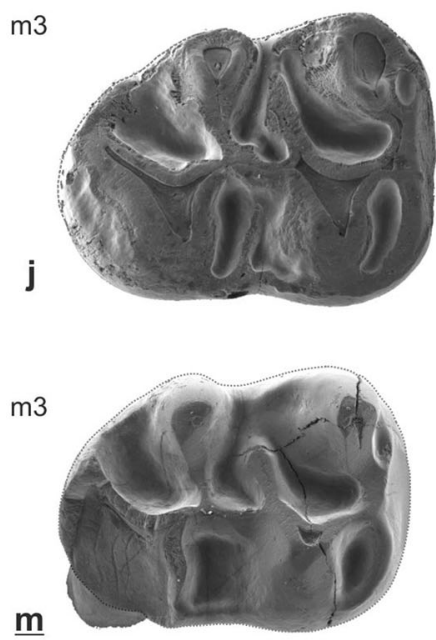

m3

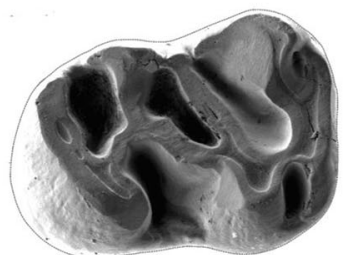

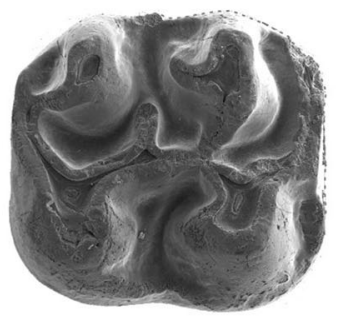
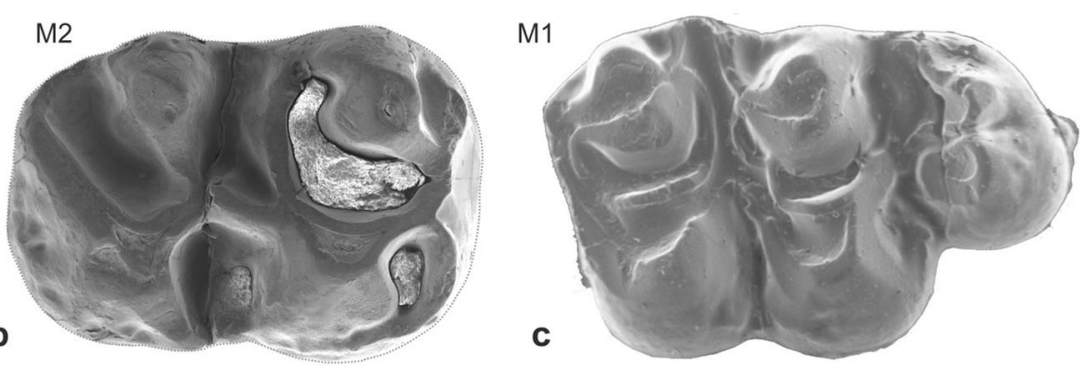

Deperetomys magnus, Paragovo

M1

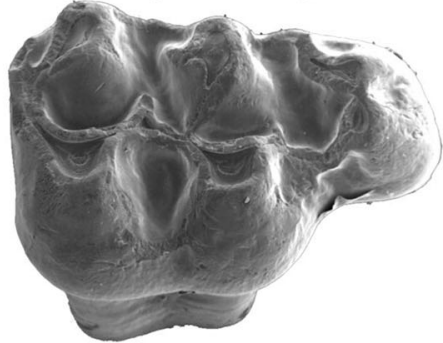

Deperetomys saltensis, Paragovo

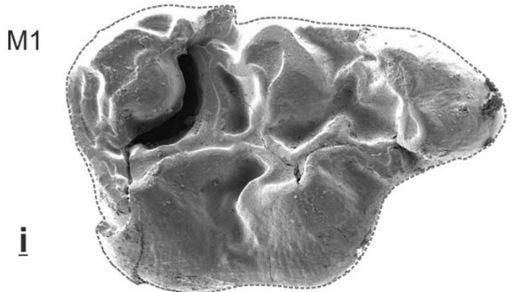

Deperetomys calefactus, Ugljevik

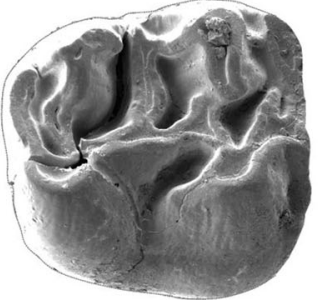

m2

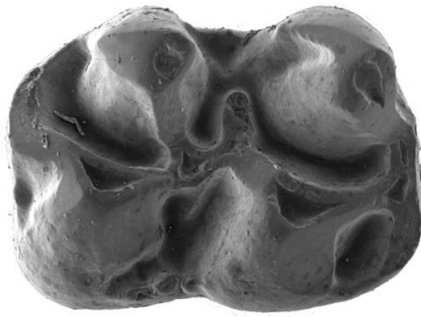

m2

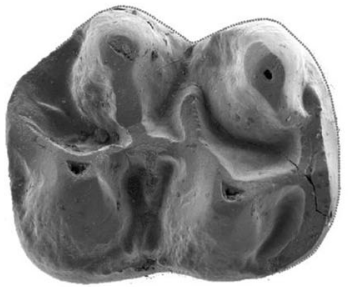

m2

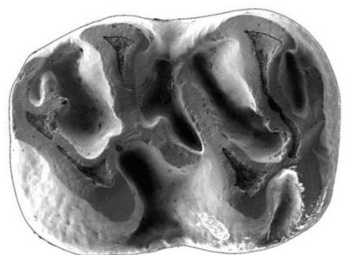

m1

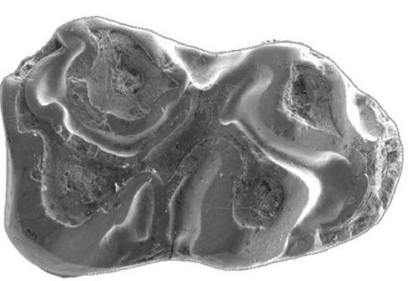

Deperetomys magnus Paragovo

m1

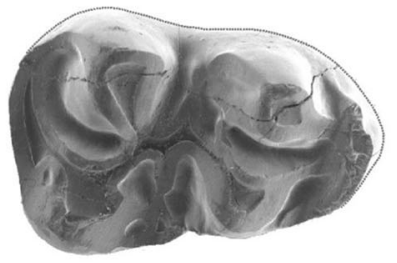

Deperetomys saltensis Paragovo

$\mathrm{m} 1$

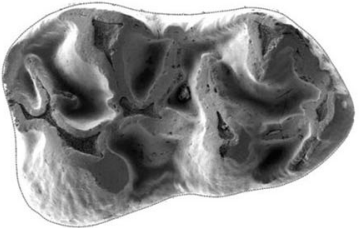

Deperetomys calefactus Ugljevik

Fig. 11 Reconstructed tooth rows of late Oligocene Deperetomys species from Paragovo and Ugljevik. a PAR015 108. b PAR015 115. c PAR015 101. d PAR015 141. e PAR015 131. f PAR015 121. g UGL015 408. h
UGL015 408. i UGL015 408. j PAR015 117. k PAR015 112. I PAR015 111. m PAR015 168. n PAR015 165. o PAR015 161. p UGL05 241. q UGL05 163. r UGL05 110 

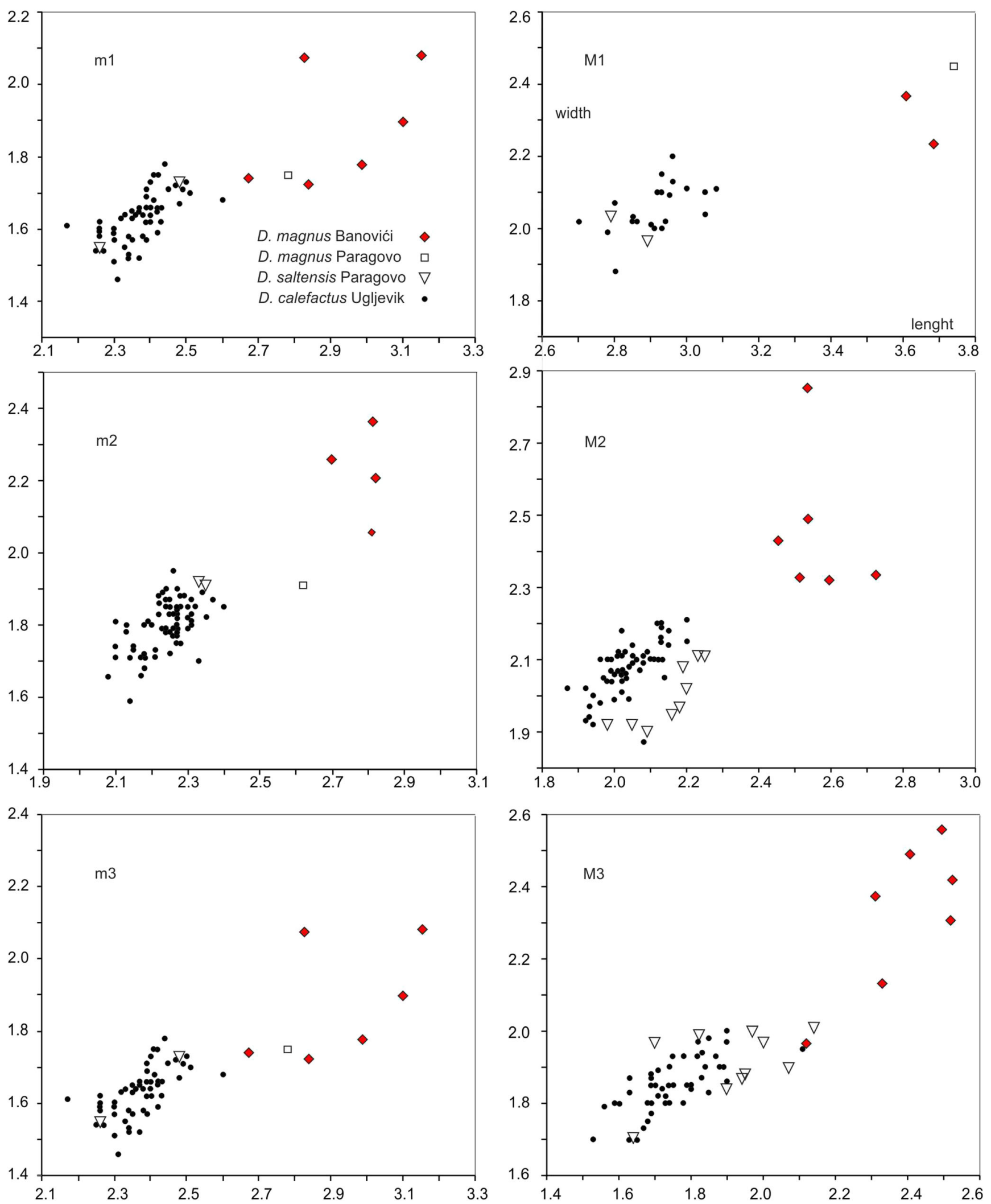

Fig. 12 Scatter diagram of Deperetomys molars. Shown are D. magnus from its type locality Banovići and from Paragovo, D. calefactus from the typse locality Ugljevik and $D$. saltensis from the type locality Paragovo 
Table 3 Measurements of Eucricetodon sp. from Ugljevik

\begin{tabular}{llllllll}
\hline & \multicolumn{1}{l}{ Length } & \multicolumn{5}{l}{ Width } \\
\cline { 2 - 3 } \cline { 6 - 7 } Ugljevik & Range & Mean & $N$ & & Mean & Range & $N$ \\
\hline M1 & $2.17-2.21$ & 2.190 & 2 & 1.480 & - & 1 \\
M2 & $1.66-1.67$ & 1.665 & 2 & 1.690 & $1.61-1.77$ & 2 \\
$\mathrm{~m} 1$ & $1.88-1.89$ & 1.885 & 2 & 1.300 & $1.24-1.36$ & 2 \\
$\mathrm{~m} 2$ & $1.71-1.80$ & 1.755 & 2 & 1.515 & $1.44-1.59$ & 2 \\
$\mathrm{~m} 3$ & $1.79-1.90$ & 1.860 & 3 & 1.450 & $1.6-1.57$ & 3 \\
\hline
\end{tabular}

The lower incisor

The enamel surface of the lower incisor shows two longitudinal ridges (Fig. 13). The enamel is thickest at the mesial end $(\sim 100 \mathrm{mu})$ and tapers out at the distal end (Fig. 14). The thick portio interna $(\sim 80 \%)$ consists of almost longitudinal uniserial Hunter-Schreger bands with the inter-prismatic matrix parallel to the prisms. The prisms change direction in a narrow zone below the mesial longitudinal ridge. The thin portio externa consists of slightly oblique prisms and is thus intermediate between radial and tangential enamel. This is schmelzmuster type 10 of Kalthoff (2000).

\section{Remarks}

For a discussion and review of Eucricetodon, we refer to van de Weerd et al. (2021). Species within Eucricetodon do not show sustained changes in dental morphology: there is no polarity in the species characteristics; Freudenthal and Martín-Suárez (2016) could not demonstrate "ancestor-descendant relationships" except within their "collatus group" of species. The genus thus shows a mosaic pattern in its species characteristics. Because of the absence of a striking and characteristic feature and considering the small size of the assemblage, we refrain from classifying the Ugljevik fossils to species.

The schmelzmuster of 11 analysed Eucricetodon samples are listed in van de Weerd et al. (2021). The two investigated early Oligocene samples have a type 1 schmelzmuster as defined by Kalthoff (2000); latest Oligocene and early Miocene samples have type 4. The late Oligocene Eucricetodon from Ugljevik has the derived type 10 enamel pattern. The enamel patterns of the late Oligocene samples from Belgaric (France) and Gözükızıll1-1 (Anatolia) are derived also. In our opinion, this suggests the presence of different lineages within the genus, so we do not share the pessimistic view of Gomes Rodrigues et al. (2013) on the usefulness of enamel microstructure in deciphering the complexities within the genus. Subfamily Eumyarioninae Ünay-Bayraktar, 1989
Genera included: Eumyarion Thaler 1966, Mirrabella de Bruijn, van den Hoek Ostende and Donovan, 2007

Genus Eumyarion Thaler, 1966

Type species: E. helveticus (Schaub, 1925)

Eumyarion cf. margueritae de Bruijn et al., 2013

(Figure 13a-c)

Type locality: Banovići, late Oligocene, Bosnia and Herzegovina

Locality: Paragovo (PAR015)

Material: M1: no. 171-173; M2: no. 175-176; M3: 1 complete, 1 incomplete, no. 178, (179).

Measurements: see Table 4

\section{Description}

M1: The M1 from Paragovo allocated to E. cf. margueritae are the same size and have the same morphology as those from the type locality of this species. The crescent-shaped anterocone has a long labial arm that reaches the paracone. The short anterior arm of the protocone does not reach the anterocone. The posterior spur of the paracone and the mesoloph vary in length. The very short protoloph inserts on the longitudinal ridge behind the protocone. The transverse metaloph connects the metacone with the hypocone. The thin posteroloph delimits a narrow postero-labial sinus.

M2: The rather elongate M2 with their symmetrical lingual and labial arms of the anteroloph and short mesoloph are very similar to the ones from Banovići. The protoloph of both specimens inserts in front of the protocone. This is a rare morphotype in the material from the type locality.

M3: Both M3 from Paragovo have a more reduced dental pattern than the ones from Banovici. The sinus is closed by the new connection between the protocone and the hypocone, the metaloph is very short and the mesoloph is vestigial. Their dental pattern is thus quite different from those from the type locality which have a morphology that is close to that of the M2.

Remarks

Although the M1 and M2 described above fit the type material of E. margueritae, the M3 are rather different. The absence of the lower cheek teeth of this species from the Paragovo assemblage creates some uncertainty about the identification on the species level, hence our allocation to E. cf. margaritae.

Eumyarion cf. microps de Bruijn and Saraç, 1991

(Figure 13d-i)

Type locality: Harami 1, early Miocene, Anatolia Locality: Paragovo (PAR015) 
M3

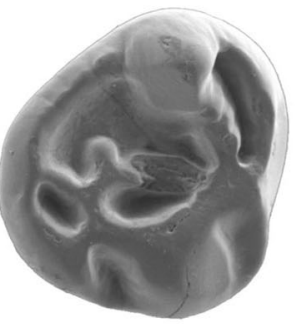

$\underline{\text { a }}$
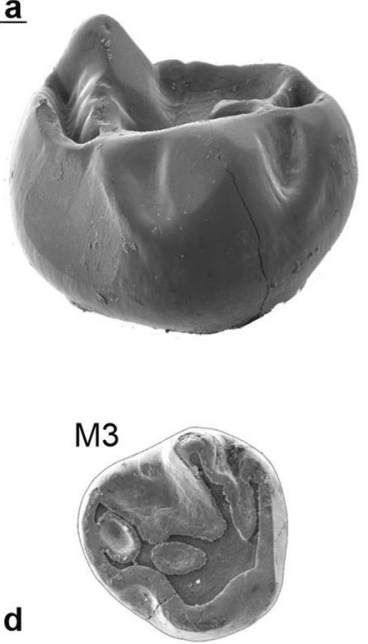

g

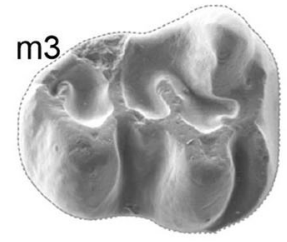

M2

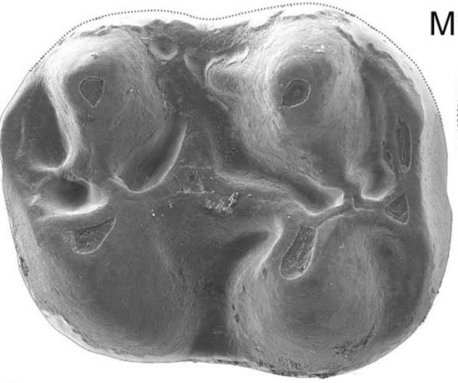

b

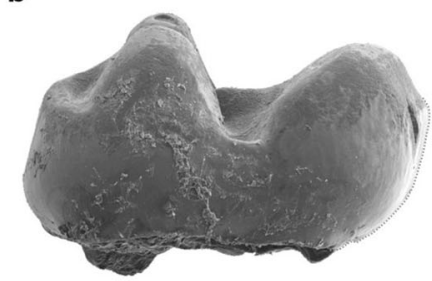

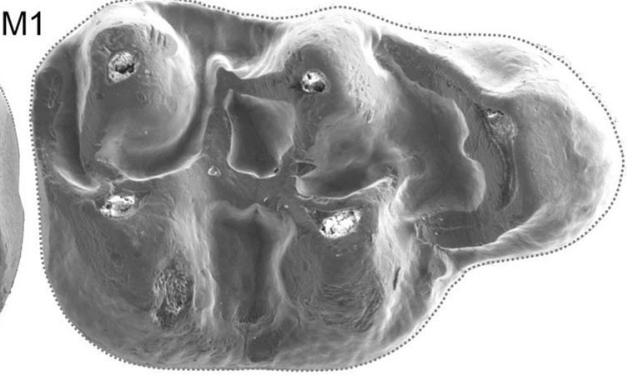

c

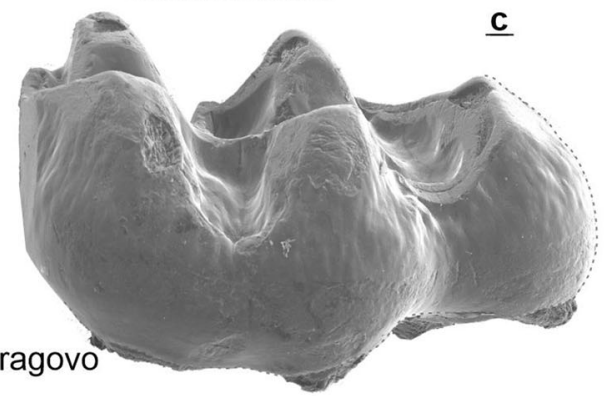

e

$\mathrm{M} 2$

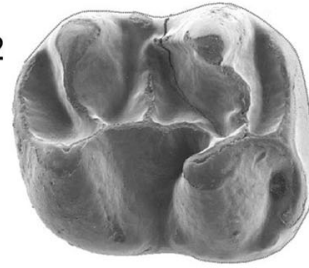

$\underline{\mathbf{h}}$

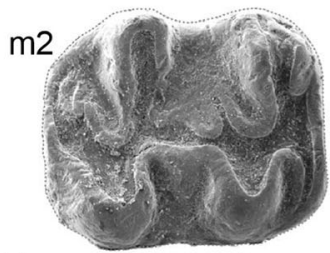

Eumyarion cf. microps Paragovo
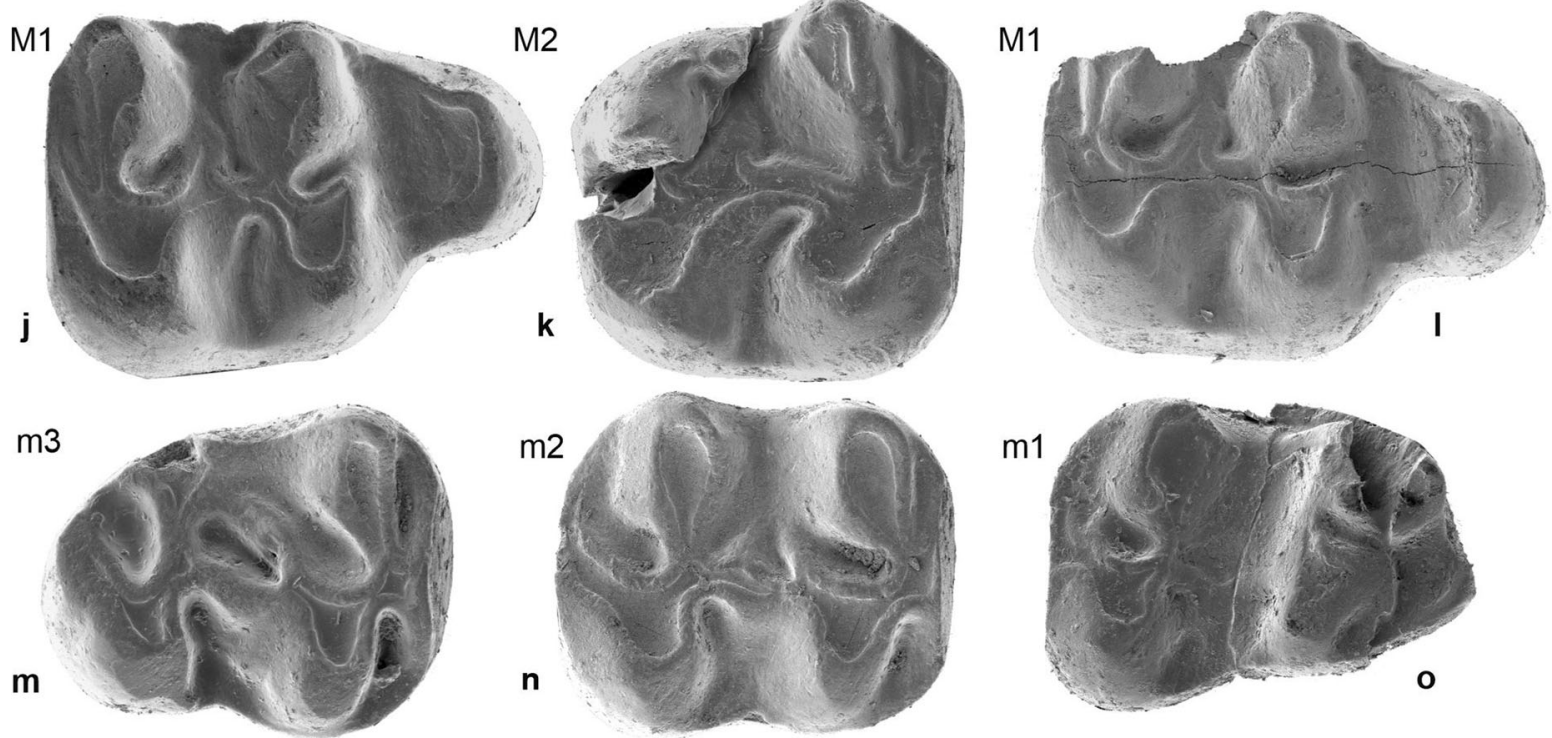

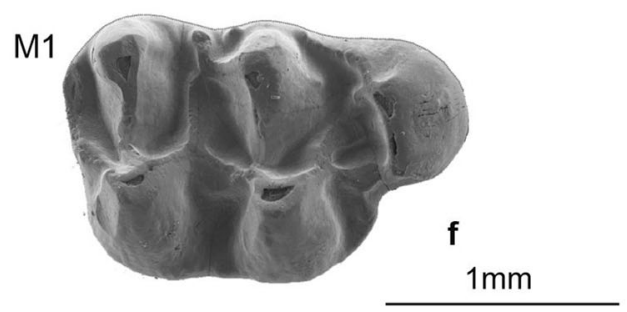

$\mathrm{m} 1$

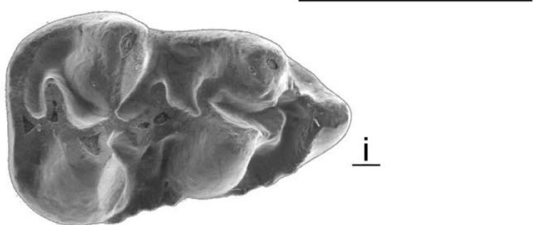

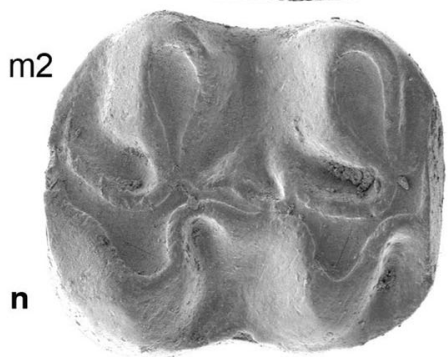

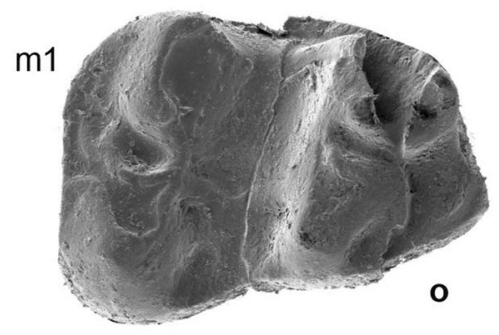

\section{Eucricetodon sp. Ugljevik}

Fig. 13 a-c Tooth rows of Eumyarion cf. margueritae occlusal and lingual view. d-i Eumyarion cf. microps from Paragovo occlusal view. $\mathbf{j}-\mathbf{0}$ Eucricetodon sp. from Ugljevik occlusal view. a PAR015 178. b
PAR015 175. c PAR015 171. d PAR015 190. e PAR015 183. f PAR015 182. g PAR015 197. h PAR015 196. i PAR015 191. j UGL05 426. k-I UGL05 432. $\mathbf{m}-\mathbf{n}-\mathbf{0}$ UGL05 431. The same number is the same individual 

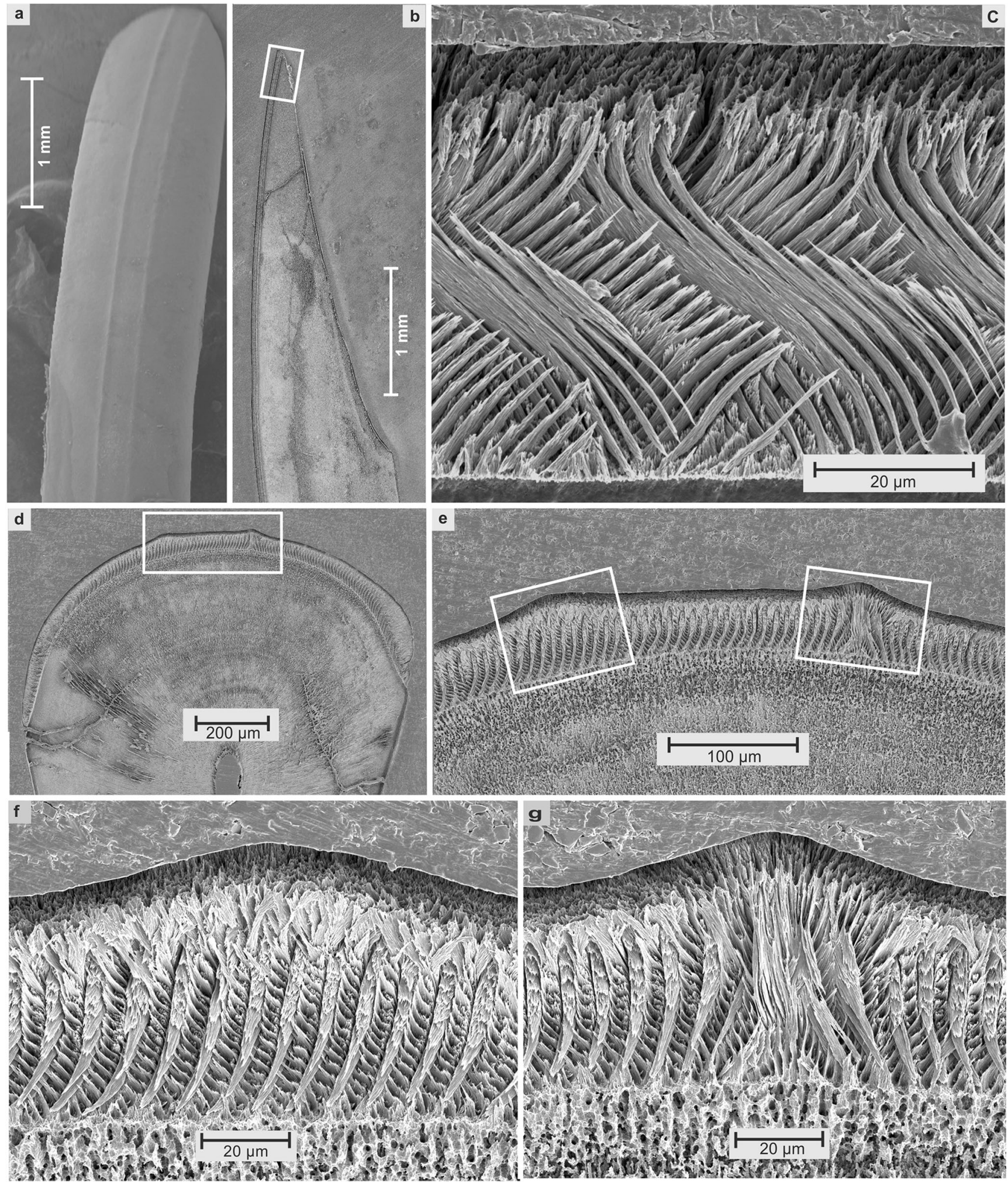

Fig. 14 The lower incisor of Eucricetodon sp. from Ugljevik. a Exterior. b Sagittal section. $\mathbf{c}$ Detail of $\mathbf{b}$. d-g Transverse sections. e Detail of d. f Detail of left box in $\mathbf{e}$. $\mathbf{g}$ Detail of right box of $\mathbf{e}$

Material: M1, no. (181) 182; M2, no. 183-187, (188); M3, no. $190 ; \mathrm{m} 1$, no. 191-193; m2, no. 194, (195), 196; m3, no. 197-200.

Measurements: Table 5
Description

M1: The anterocone of the M1 is incipiently bifid as it is in the specimens from the type locality. The weak lingual and labial 
Table 4 Measurements of Eumyarion cf. margaritae from Paragovo

\begin{tabular}{|c|c|c|c|c|c|c|c|c|}
\hline \multirow[b]{2}{*}{ Paragovo } & \multicolumn{4}{|l|}{ Length } & \multicolumn{4}{|l|}{ Width } \\
\hline & Range & Mean & $\mathrm{N}$ & SD & Range & Mean & $\mathrm{N}$ & SD \\
\hline M1 & $2.22-2.26$ & 2.240 & 3 & 0.021 & $1.37-1.46$ & 1.430 & 3 & 0.049 \\
\hline M2 & $1.53-1.61$ & 1.570 & 2 & --- & $1.39-1.40$ & 1.400 & 2 & --- \\
\hline M3 & --- & 1.290 & 1 & --- & --- & 1.360 & 1 & --- \\
\hline
\end{tabular}

arms of the anterocone reach the base of the protocone and paracone. The anterior arm of the protocone ends free. The protoloph inserts on the longitudinal ridge just behind the protocone and the transverse metaloph inserts on the hypocone. The long mesoloph is connected to the posterior spur of the paracone. The posteroloph delimits a narrow postero-labial sinus.

M2: The anterolophule divides the anteroloph into a longer labial branch and a shorter lingual branch. The parallel protoloph and metaloph insert respectively in front of the protocone and hypocone. The length of the mesoloph and the development of the posterior spur of the paracone show considerable individual variation. The thin posteroloph reaches the base of the metacone.

M3: The single available M3 from Paragovo is rather worn. Its dental pattern, showing a slightly forward-directed protoloph, a short mesoloph and metaloph, is the same as in the M3 from Harami-1.

m1: The rather high-pointed anteroconid is connected to the metaconid by a low metalophulid 1 . A very thin anterolophulid connects the protoconid and the anteroconid. The metalophulid 2 is formed by the posterior arm of the protoconid. The longitudinal ridge is much lower than the cusps and bears a short mesolophid as well as a welldeveloped ectomesolopid. The long posterior arm of the hypoconid ends free in the postero-lingual sinus. The posterolophid reaches the base of the entoconid.

m2: Two of the three $\mathrm{m} 2$ available from Paragovo are rather worn, and the third is slightly damaged anteriorly, so details of the anterolopid-metalophulid 1 are not preserved. It seems, however, that the metalophule 1 is situated very close to the

Table 5 Measurements of Eumyarion cf. microps from Paragovo

\begin{tabular}{|c|c|c|c|c|c|c|c|c|}
\hline \multirow[b]{2}{*}{ Paragovo } & \multicolumn{4}{|l|}{ Length } & \multicolumn{4}{|l|}{ Width } \\
\hline & Range & Mean & $\mathrm{N}$ & SD & Range & Mean & $\mathrm{N}$ & SD \\
\hline M1 sup & --- & 1.69 & 1 & --- & --- & 1.17 & 1 & --- \\
\hline M2 sup & $1.14-1.31$ & 1.220 & 6 & 0.066 & $1.04-1.15$ & 1.120 & 6 & 0.051 \\
\hline M3 sup & --- & 0.89 & 1 & --- & --- & 0.93 & 1 & --- \\
\hline $\mathrm{m} 1 \mathrm{inf}$ & $1.36-1.46$ & 1.410 & 3 & 0.050 & $0.89-0.95$ & 0.930 & 3 & 0.035 \\
\hline $\mathrm{m} 2 \mathrm{inf}$ & $1.23-1.25$ & 1.240 & 2 & --- & $0.95-1.01$ & 0.980 & 3 & 0.031 \\
\hline $\mathrm{m} 3 \mathrm{inf}$ & $1.09-1.17$ & 1.130 & 4 & 0.033 & $0.90-0.97$ & 0.940 & 4 & 0.032 \\
\hline
\end{tabular}

lingual arm of the anterolophid and became fused with that ridge at an early stage of wear. The posterior arm of the protoconid and the mesolophid show considerable individual variation in length. The posterior arm of the hypoconid ends free in the postero-lingual sinus.

m3: The labial arm of the anterolophid is exceptionally strong, just as is the case in the type material of E. microps. The short lingual branch ends against the base of the metaconid. The metalophulid 1 is forward-directed and so is the hypolophid which inserts on the longitudinal ridge in front of the hypoconid. The figured specimen shows the remnant of the posterior arm of the hypoconid, in the three others this ridge is absent. The rather strong posterolophid connects to the entoconid.

\section{Remarks}

The morphology of the small Eumyarion teeth described above is surprisingly similar to that of the specimens of E. microps from its early Miocene-type locality Harami, but they are somewhat larger. If the material from Paragovo could have been enlarged, a small overlap in size of all the cheek teeth with the type material of that species is expected. On the basis of biostratigraphical data, we estimate that of the three localities that have yielded E. microps, Paragovo is the older and Harami 1 the younger. Supposing the age sequence Paragovo - Banovići - Harami 1 is correct, the species Eumyarion microps shows a gradual decrease in size through time. The E. microps assemblage from Gökler in Anatolia (Joniak et al. 2017) is very similar in size to that of Harami and thus confirms the observed trend. Although size decrease in evolutionary lineages must have been a common phenomenon, it has, in contrast to size increase, rarely been convincingly documented in the fossil record of the rodents.

Family Spalacidae Gray, 1821

Introduction

De Bruijn et al. (2013) were the first to describe a spalacid genus and species, Vetusspalax progressus, from the late Oligocene. The antiquity of this family going back to the Oligocene was long suspected (Hugueney and Mein 1993) considering the diversity of the family in the early Miocene with the genus Heramys Klein Hofmeijer and de Bruijn 1985 in the early Miocene of Aliveri (Greece) and Debruijnia Ünay, 1996 from the early Miocene of Keseköy (Turkey). Late Oligocene Vetusspalax is sufficiently different from both Heramys and Debruijnia to suspect that there is no ancestordescendant relation between these. Below, we describe another genus that we include in the Spalacidae. This new genus, about contemporaneous with Vetusspalax from Banovići, is again not very close in dental morphology to the early 
a
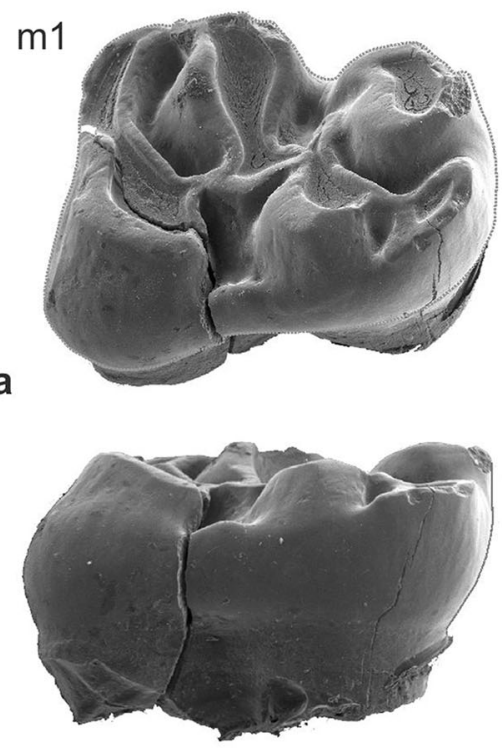

b
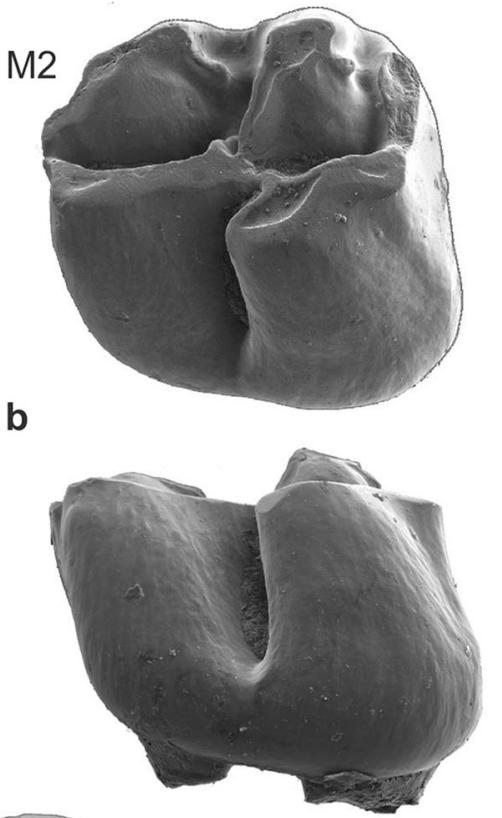

M1

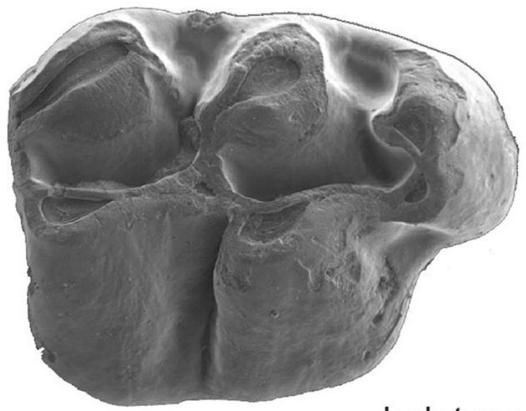

C

holotype

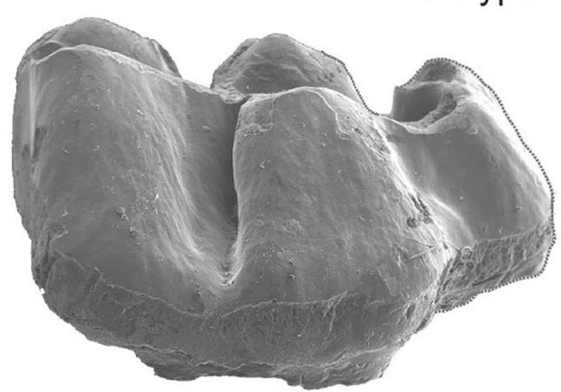

d

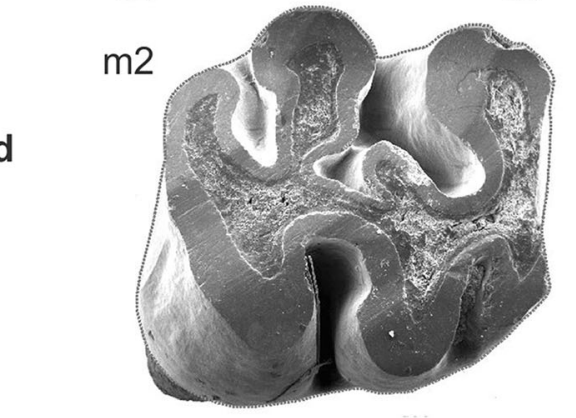

$1 \mathrm{~mm}$

$1 \mathrm{~mm}$

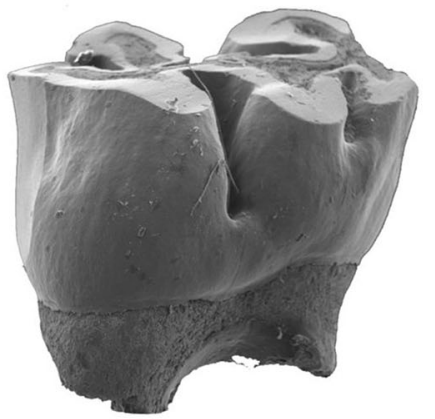

Pannoniamys paragovensis n. gen. n. sp.

Fig. 15 Pannoniamys paragovensis nov. gen. nov. sp. from Paragovo. a and $\mathbf{d}$ are occlusal and labial views. $\mathbf{b}$ and $\mathbf{c}$ are occlusal and lingual views. a PAR015 206. b PAR015 203. c PAR015 201. d PAR015 209

Miocene genera Heramys and Debruijnia, so an ancestordescendant relation with these genera is not likely.

Genus Pannoniamys nov. gen.

Type species: Pannoniamys paragovensis nov. sp.

Derivatio nominis: The genus is named after the ancient Roman province Pannonia Inferior, where the type locality of its type species is located.

Table 6 Measurements of Pannoniamys paragovensis nov. sp. from Paragovo

\begin{tabular}{|c|c|c|c|c|c|c|}
\hline \multirow[b]{2}{*}{ Paragovo } & \multicolumn{3}{|l|}{ Length } & \multicolumn{3}{|l|}{ Width } \\
\hline & Range & Mean & $\mathrm{N}$ & Range & Mean & $\mathrm{N}$ \\
\hline M1 & --- & 2.49 & 1 & --- & 2.07 & 1 \\
\hline M2 & $1.79-1.90$ & 1.850 & 2 & $1.89-1.98$ & 1.940 & 2 \\
\hline $\mathrm{m} 1$ & $2.15-2.20$ & 2.180 & 2 & $1.64-1.72$ & 1.680 & 2 \\
\hline $\mathrm{m} 2$ & $1.95-2.17$ & 2.060 & 2 & $1.73-1.80$ & 1.770 & 2 \\
\hline
\end{tabular}

Diagnosis: Cheek teeth robust and low-crowned. Anterocone(id) of the $\mathrm{M} 1 / \mathrm{m} 1$ not incorporated into the anteroloph(id). Protoloph and metaloph of the M1 and M2 directed posteriorly and connected to the mesocone/posteroloph. Metalophulid 1 absent in the $\mathrm{m} 1$, forward-directed in the $\mathrm{m} 2$. Metalophulid 2 formed by the poster arm of the protoconid in the $\mathrm{m} 1$, absent in the $\mathrm{m} 2$. Posterior arm of the hypoconid absent in the $\mathrm{m} 1, \mathrm{~m} 2$. Mesoloph absent in the M1, M2. Mesolophid absent in the m1, $\mathrm{m} 2$.

Differential diagnosis: The cheek teeth of Pannoniamys paragovensis are about the same size and about as robust as those of the type species of Debruijnia (D. arpati Ünay, 1996), but they are more brachyodont, lack the anterior arm of the protocone and the mesoloph in M1, M2 as well as the mesolophid and the posterior arm of the hypoconid in the $\mathrm{m} 1$, $\mathrm{m} 2$. The M1, M2 of the type species of these genera differ furthermore in the direction of the protoloph and metaloph. These lophs are more or less transverse in Debruijnia, but posteriorly directed in Pannoniamys. The lower molars show similar differences: the mesolophid and the posterior arm of 
cf. Daxneria

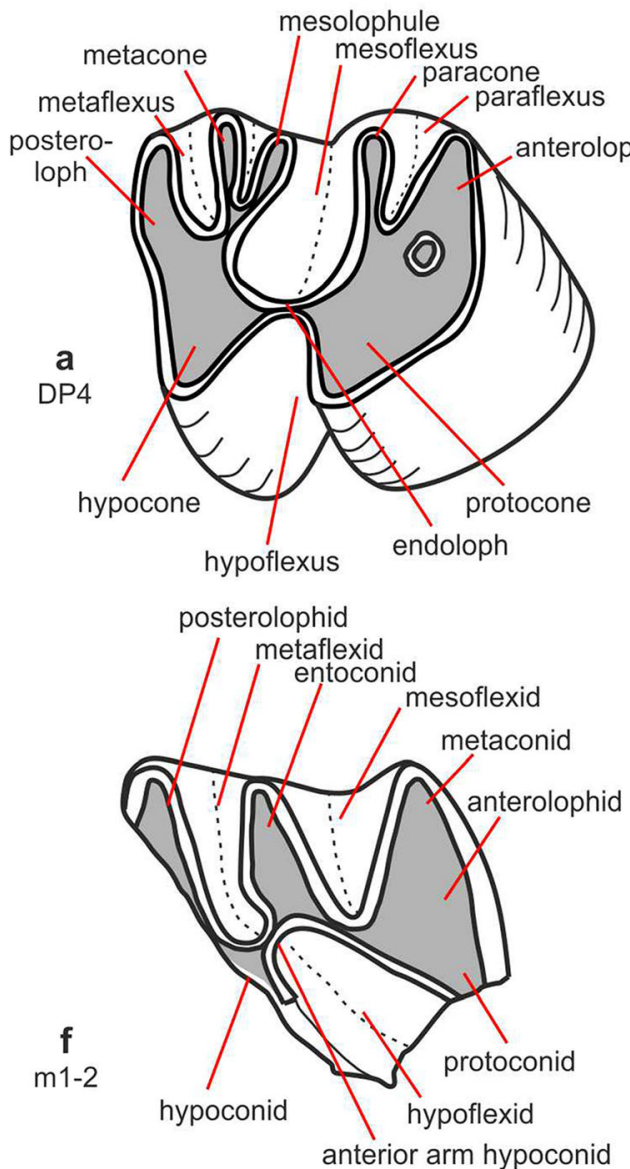

anterior arm hypoconid

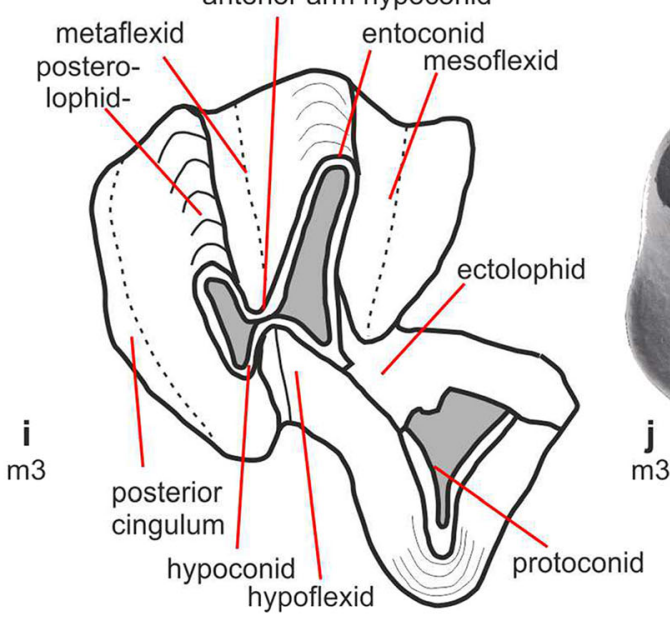

Fig. 16 Line drawings of cf. Daxneria from Ugljevik and nomenclature of tooth parts used in the description: a DP4 (or M1-2; UGL05 475), f m2 (UGL05 471), and i m3 (UGL05 473) Daxneria fragilis van de Weerd
Daxneria fragilis
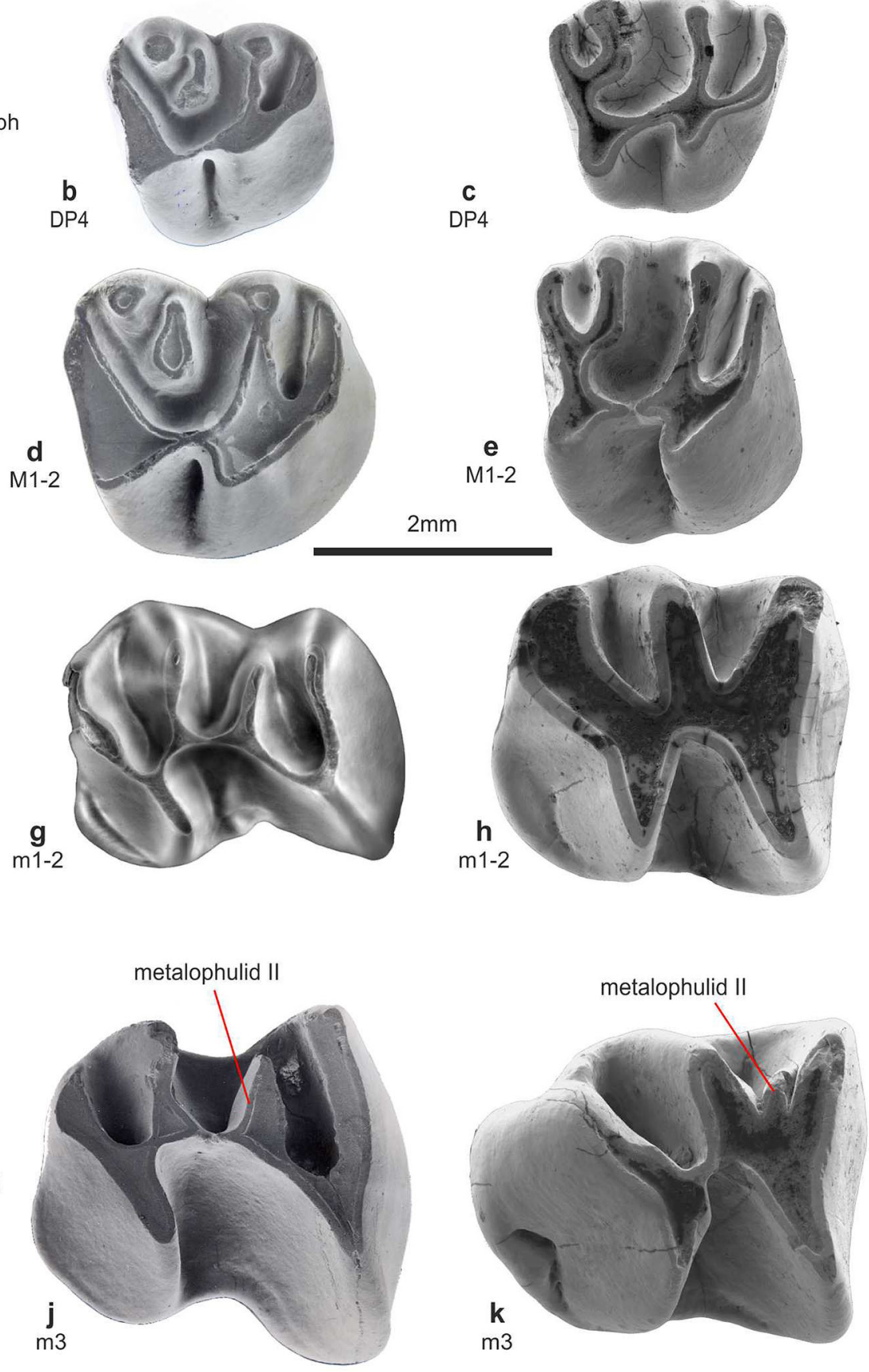

Sayimys giganteus
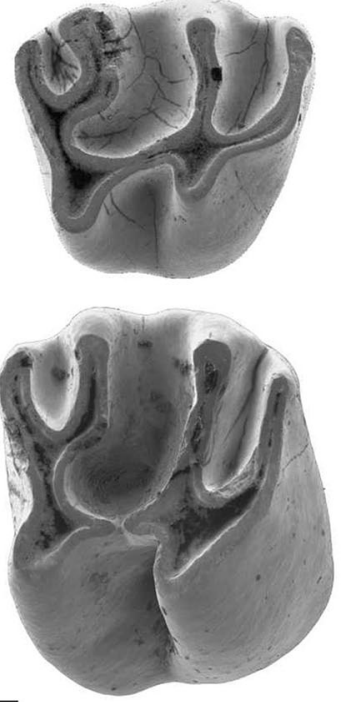


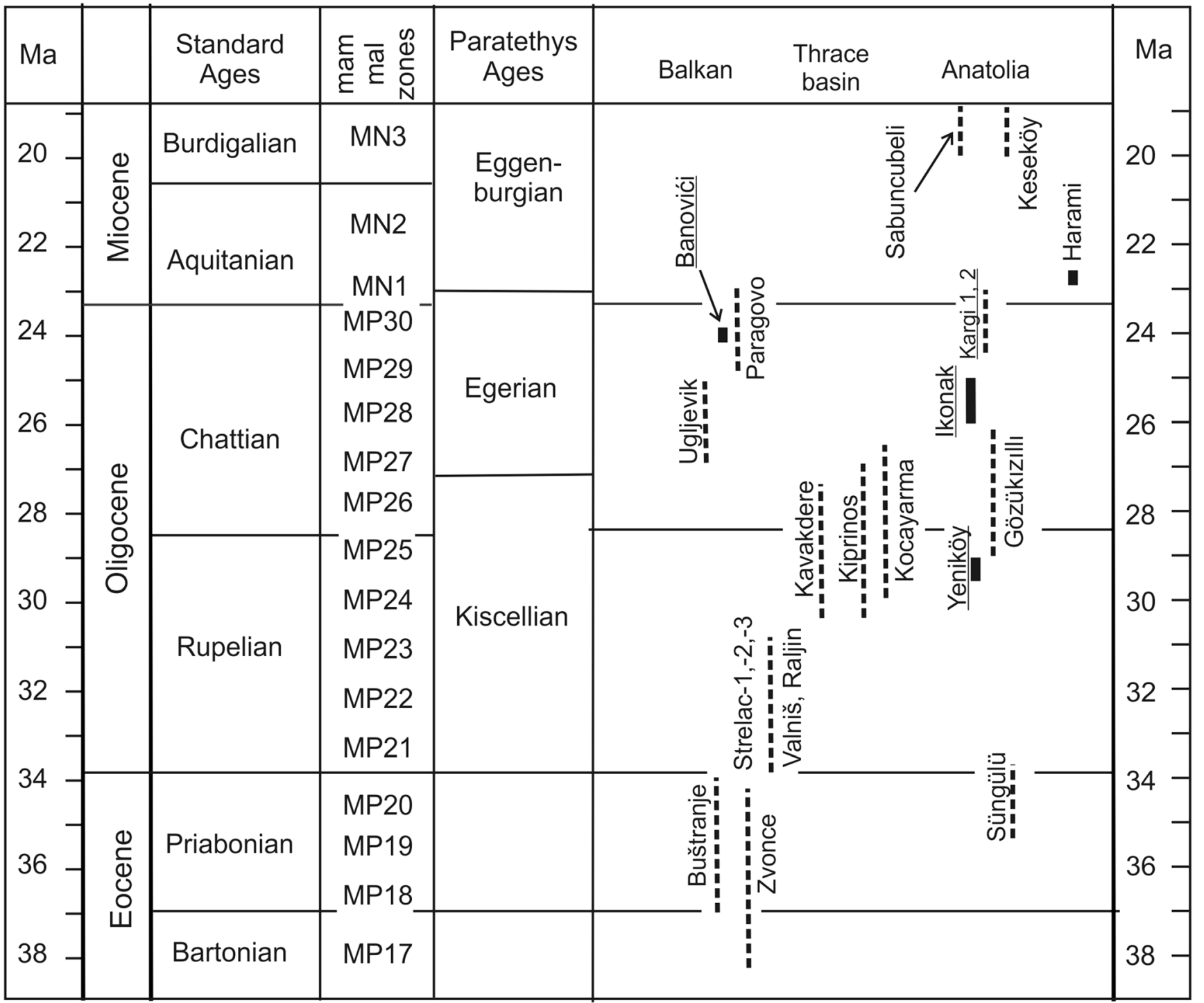

Fig. 17 Chronostratigraphic scheme of Paleogene and early Neogene faunas from the Balkans and Asia Minor. Broken lines indicate uncertainty ranges, duration of these are arbitrarily set at $8 \%$ of the estimated age. Locations with a magneto-stratigraphic age estimate have a solid line and names are underlined. References on the sites are Banovići (de Bruijn et al. 2013), Gőzık1zıll1-1 (van de Weerd et al. 2021), Buštranje, Strelac, Valniš, Zvonce (de Bruijn et al. 2018), Harami, Inkonak, Karg1, Yeniköy, Keseköy (Krijgsman et al. 1996; Ünay et al. 2003), Kavakdere, Kocayarma (Ünay-Bayraktar 1989), Kyprinos (Doukas and Theocharopoulos 1999), Paragovo, Ugljevik (this paper), Sabuncubeli (de Bruijn et al. 2006) and Süngülu (de Bruijn et al. 2003)

Type locality: Paragovo (PAR015)

Holotype: M1sin. no. 201

Material: M1: no 201; M2: no. 203-204; m1: no. 206-207; m2: no. 209-210.

Measurements: see Table 6

\section{Description}

M1: The anterocone of the M1 is not incorporated into the anteroloph and indistinctly divided into two cusps by an indentation on the posterior side. The lingual cusp of the anterocone is connected to the protocone by a strong anterolophule, while the labial cusp is not connected to the 
paracone. The protocone and paracone are about the same size. The paracone is connected to the longitudinal ridge by a short posteriorly directed protoloph. The shallow lingual sinus is directed slightly forward. There is no mesoloph and the posteriorly situated metacone is in direct contact with the short, weak posteroloph. The hypocone is developed as a ridge rather than as a cusp. The roots of the M1 are not preserved.

M2: The shape of the occlusal surface of the M2 is sub-square. The lingual arm of the anteroloph is absent, while the short, thin labial branch ends in a small, oval cusp. The four main cusps are about equal in size. The short protoloph is directed posteriorly and connects the paracone to the longitudinal ridge. The metacone is incorporated into the posteroloph. The roots of the M2 are not preserved.

m1: The small anteroconid is connected to the protoconid by a very weak anterolophulid, but is separate from the metaconid. The anterosinusid is tiny. The metaconid is situated more forward than the protoconid, which is a characteristic shared by the $\mathrm{m} 1$ of all spalacids. The metalophulid 1 is absent, while the metalophulid 2 is formed by the posterior arm of the protoconid. The sinusid is more or less transverse. There is not the slightest trace of a mesolophid. The large entoconid is connected to the mesoconid by a very short hypolophid. The strong posterolophid reaches the entoconid. The roots of the $\mathrm{m} 1$ are not preserved.

$\mathbf{m} 2$ : The metaconid of the $\mathrm{m} 2$ gets incorporated into the lingual branch of the anterolophid at an early stage of attrition, but the anterosinusid remains visible until the tooth is completely worn. The short posterior arm of the protoconid ends free. The hypolophid is transverse in one $\mathrm{m} 2$, but directed forward in the other. The strong posterolophid does not connect to the entoconid until a late wear stage

\section{Remarks}

The main reasons to allocate Pannoniamys to the Spalacidae are the robustness of its semi-hypsodont cheek teeth with relatively thick enamel, in combination with the forward position of the metaconid in the $\mathrm{m} 1$ and $\mathrm{m} 2$. The discovery of two more or less contemporaneous spalacid genera in the same area shows that the diversity of the family during the late Oligocene was much greater than expected and suggests that this area was the cradle of this clade. It also supports the fossil record-based phylogenetic position of the Spalacidae relative to the Rhizomyidae and Tachyoryctoidinae (de Bruijn et al. 2015) rather than the molecular-based reconstruction (Jansa et al. 2009) and that based on a combination of these disciplines (He et al. 2019). Since the late Oligocene Vetusspalax, Pannoniamys and the early Miocene spalacides Debruijnia and Heramys are exclusively known by their teeth, we are not in a position to establish whether or not these early members of the Spalacidae were fossorial. Considering dental morphology of the Miocene spalacides Debruijnia, Heramys and Pliospalax (including Sinapospalax) were probably fossorial.

Suborder Ctenohystrica Huchon, Catzeflis and Douzery, 2000 Infraorder Hystricognathi Tullberg, 1899

Subfamily Baluchimyinae Flynn, Jacobs and Cheema, 1986

cf. Daxneria van de Weerd, Wessels and de Bruijn, 2021

(Figure 16a, f, i)

Locality: Ugljevik (UGL05)

Material: one upper incisor, one broken and repaired DP4; two partial lower cheek teeth $\mathrm{m} 1-2$ and $\mathrm{m} 3$, probably all from a single individual.

Measurements: DP4 no. 475 , length $\times$ width $3.08 \times 2.58 \mathrm{~mm}$; damaged $\mathrm{m} 2$ no. $471,2.57 \times 2.16 \mathrm{~mm}$; damaged $\mathrm{m} 3$ : no. 473 , $3.25 \times 3.46 \mathrm{~mm}$, diagonal width $3.39 \mathrm{~mm}$.

\section{Description}

The material of this large rodent with hypsodont teeth consists of parts of teeth with very thin enamel.

Upper incisor: the upper incisor shows a shallow sulcus.

DP4 or possibly M1 or M2 dext.: This tooth was broken in two parts and repaired. The occlusal surface is flat. Paraflexus and metaflexus are short and shallow, soon to disappear with increasing wear. In addition, there is a short and shallow flexus between mesolophule and metacone. The mesoflexus is long and very deep. A small enamel island is present in the anteroloph; it is a remnant of the initially longer paraflexus. The endoloph is narrow.

$\mathbf{m} 1$ or $\mathbf{m} 2$ sin, shown in mirror image: It is rather worn and has a flat occlusal surface. Protoconid and hypoconid are broken off. The flexids are of about equal depths.

The metaconid is fused with anterolophid and protoconid forming the anterior triangular prism of the occlusal surface. The metaflexid is curved anteriorly forming a sort of constriction in the entolophid. The entolophid and anterior arm of the hypoconid are narrow.

m3 dext.: the anterolophid and metaconid areas are broken off. The parts of the preserved occlusal surface are in a single plane. The three flexids are all deep. The protoconid is strongly protruding in labial direction and narrow at its end. The hypoconid and posterolophid form the confluent posterior part of the molar. There is no inflexion separating the hypoconid from the posterolophid. A low but well-developed posterior cingulum is present.

Remarks

Parts of high-crowned cheek teeth and an upper incisor of a large rodent are present in the association from Ugljevik. 
These are too fragile to have them cleaned, coated and photographed in the electron microscope, and therefore, we illustrate these with simple line graphs. The material resembles the baluchimyine Daxneria van de Weerd et al. (2021) from the Oligocene of Gözükızıllı-1 (Anatolia).

The three fragments described above are considered to belong to Daxneria; however, we leave the possibility open that the m1-2 belongs to Sayimys. Figure 16 compares the Ugljevik fossils with the corresponding elements of Daxneria fragilis from Gözükızıllı-1 and Sayimys giganteus López-Antoñanzas, Sen and Saraç, 2004 from Keseköy. The DP4 (or M1-2) from Ugljevik clearly shows a mesolophule, a characteristic feature of Daxneria, absent in Sayimys. Lower molars of Daxneria have a prominent metalophulid II; Sayimys giganteus does not (Fig. 16h) or it has a rudimentary one (Fig. 16k). The metalophulid II is not preserved on the Ugljevik partial $\mathrm{m} 3$ (Fig. 16i) and is clearly absent on the Ugljevik m1-2 (Fig. 16f). Considering the characteristic protruding narrow protoconid of the Ugljevik m3 (Fig. 16i), we allocate this molar together with the DP4 (Fig. 16a) to Daxneria, but the teeth have distinctly higher crowns than those from Gözükızıll1-1. The m1-2 from Ugljevik is similar to Sayimys in the absence of the metalophulid II, but considering the unknown variability of Daxneria from Ugljevik, we tentatively include it in that genus.

\section{Faunal composition and biostratigraphy}

Magneto-stratigraphy of the infill of the Banovići basin suggests an age of 24-23 Ma and an age for the rodent assemblage of $24 \mathrm{Ma}$ (de Leeuw et al. 2011; de Bruijn et al. 2013). The rodent assemblages from Paragovo (Serbia) and nearby Banovići (Bosnia and Herzegovina, Fig. 1) share Deperetomys magnus, Eumyarion margueritae, E. microps and Microdyromys praemurinus and are thus considered to have similar ages (Fig. 17). The fauna from Ugljevik is slightly older, because its Deperetomys is more primitive than that of Paragovo and Banovići (Marković et al. 2019). The number of small mammal assemblages from the Paleogene of the Balkans and the offsetting region of Asia Minor is still rather limited (Fig. 17). The associations from Ugljevik, Paragovo and Banovići do not allow us to draw sweeping conclusions about the development of the rodent communities in the northern Balkans during the late Oligocene, because their absolute and relative ages are uncertain, the number of specimens per locality is limited and samples have been collected from different sedimentary environments and therefore probably document different biotopes. The great difference in composition and diversity between the association from Ugljevik on the one hand and those from Paragovo and Banovići (Fig. 7) on the other hand is almost certainly largely due to difference of the sampled biotopes rather than to difference in age. The fossils from Ugljevik come from the main coal seam which contains abundant poorly preserved frog remains. The dominating Deperetomys calefactus is primarily represented by skull and mandible remains suggesting that this hamster lived within the marsh itself. Other rodents are very rare and mainly represented by isolated teeth which may have been brought in by birds of prey. The Paragovo material has been collected from a fluviatile clay and the Banovići association comes from a lacustrine lignitic clay with limestone nodules.

The presence of tooth fragments of a baluchimyine in Ugljevik indicates affinity with the late Oligocene fauna from Gözükızıll1-1 in Central Anatolia (van de Weerd et al. 2021). Eomys on the other hand is absent east of the Bosporus, but common in Thrace as well as in Europe. The murid Deperetomys, the only fauna element that all three assemblages share, may well have originated in situ during the early Oligocene. The assemblage from Paragovo contains a number of newcomers for the Balkans: Microdyromys arrived from Europe and Eumyarion and Plesiosminthus presumably from Asia. The absence of eomyids in the Paragovo community is not understood, but does not seem to be due to sampling bias since there is no trace of eomyids in Banovići either. The presence of two species of Deperetomys that are both different from the one in Ugljevik is considered to be due to age difference (Fig. 7). The glirids (Bransatoglis) appear for the first time in Ugljevik, and the first sciurids (Dehmisciurus obtusidens and Palaeosciurus aff. feignouxi) have been found in the assemblage from Banovici, while this locality yielded also the oldest lagomorph remains from the Balkans.

Early subsidence of the Pannonian basin was poorly dated, $20 \mathrm{Ma}$ (Eggenburgian = early Burdigalian) was the oldest available date for the start of the rifting (see Horváth et al. 2006). The rodent assemblages from Paragovo in the Fruška Gora and the coals of Ugljevik are estimated to be 4 to $6 \mathrm{Ma}$ older. These biostratigraphic dates confirm the Oligocene age of early extension in the Pannonian basin as suggested by Toljić et al. (2013).

\section{Conclusions}

The documentation of rodent faunas from the late Oligocene of the Balkans is still poor, but it is clear that this record strongly deviates from that in Central and Western Europe where Maridet et al. (2007) observed faunal homogeneity (high interregional connectivity) prior to the early Miocene. Late Oligocene faunas from the Balkans contain Deperetomys, Mirrabella, Vetusspalax, Pannoniamys and Daxneria (Fig. 7) genera that are absent in Central and Western Europe during that period. The pre-Alpine seaways separating the Balkans from Central Europe still formed a major zoogeographic boundary. Comparison of the rodent associations from the late 
Oligocene of the northern Balkans with the early Oligocene from southern Serbia (Marković et al. 2019) shows that the Sciuridae, Gliridae, Eomyidae, Eumyarion, Plesiosminthus and Mirrabella appear in the Balkans during the late Oligocene. Other than the allocation of a single molar from Raljin to Deperetomys, the early Oligocene assemblages do not share a single genus with the late Oligocene assemblages (Fig. 7). Contrary to the endemic evolution of the Oligocene rodent communities in western and central Europe, the available information from the Balkans suggests a regime of replacement by groups from Asia as well as from Europe.

Acknowledgements We want to express our gratitude to all those who contributed to the success of our research of the Serbian Paleogene. Miloš Milivojevic contributed essentially to the success of our field work in the Balkans. We thank Jovan Stojanović and the hotel Nina team for the way they cared for us during our stays in Babušnica and Mile Ilić for his hospitality on the premises of the old Ljuberadja watermill. The support by the staff of the Bogutovo Selo mine near Ugljevik, in particular Svetlana Renovica, head of the geology department and her staff is gratefully acknowledged. The direction and staff of the Fruška Gora National Park (Paragovo) are thanked for permissions and support. The SEM pictures of enamel were made by Hans Meeldijk and those of the cheek teeth by Tilly Bouten, Utrecht University. Figure 1 was prepared by Margot Stoete. The paper benefited from the constructive comments of the reviewers Peter Joniak (Comenius University, Bratislava) and Lars van den Hoek Ostende (Naturalis Biodiversity Centre, Leiden).

Funding This work was financially supported by the Ministry of Culture of the Republic of Serbia and the "Hans de Bruijn" Foundation.

\section{Declarations}

Conflict of interest The authors declare that they have no conflict of interest.

Open Access This article is licensed under a Creative Commons Attribution 4.0 International License, which permits use, sharing, adaptation, distribution and reproduction in any medium or format, as long as you give appropriate credit to the original author(s) and the source, provide a link to the Creative Commons licence, and indicate if changes were made. The images or other third party material in this article are included in the article's Creative Commons licence, unless indicated otherwise in a credit line to the material. If material is not included in the article's Creative Commons licence and your intended use is not permitted by statutory regulation or exceeds the permitted use, you will need to obtain permission directly from the copyright holder. To view a copy of this licence, visit http://creativecommons.org/licenses/by/4.0/.

\section{References}

Aguilar, J. P. (1977). Les gisements continentaux de Plaissan et de la Nouvelle Faculté de Médecine (Hérault), leur position stratigraphique. Géobios, 10, 81-101.

Bahlo, E. (1975). Die Nagetierfauna von Heimersheim bei Alzey (Rheinhessen, Westdeutschland) aus dem Grenzbereich Mittel-/ Oberoligozän und ihre stratigrafische Stellung. Abhandlungen Hessisches Landesamt für Bodenforschung, 71, 1-182.
Baudelot, S. (1970). Compléments à l'étude des micromammifères du gisement Miocène de Sansan (Gers). Comptes Rendus sommaires Société Géologique de France, 8, 303-304.

Berger, G. (2008). Die fossilen Schlafmäuse (Gliridae, Rodentia, Mammalia) aus süddeutschen Spaltenfüllungen des Obereozäns und Unteroligozäns. Münchner Geowissenschaftliche Abhandlungen, A41, 1-128.

Bowdich, T. E. (1821). An analysis of the natural classifications of Mammalia, for the use of students and travellers. Paris: J. Smith.

Bruijn, H. de (1966). Some new Miocene Gliridae (Rodentia, Mammalia) from the Calatayud Area (prov. Zaragoza, Spain). Proceedings Koninklijke Nederlandse Academie van Wetenschappen, B69, 1-21.

Bruijn, H. de (1967). Gliridae, Sciuridae y Eomyidae (Rodentia, Mammalia) miocenos de Calatayud (provincia de Zaragoza, España) y su relación con la bioestratigrafía del area. Boletin Instituto Geológico Minero de España, 78, 187-373.

Bruijn, H. de (1976). Vallesian and Turolian rodents from Biotia, Attica and Rhodes (Greece), Proceedings of the Koninklijke Nederlandse Akademie van Wetenschappen, Series B 79, 361-384.

Bruijn, H. de \& Saraç, G. (1991). Early Miocene rodent faunas from the eastern Mediterranean area. Part I. The genus Eumyarion. Proceedings of the Koninklijke Nederlandse Akademie Van Wetenschappen, 94(1), 1-36.

Bruijn, H. de, Fahlbusch,V., Saraç, G., \& Ünay, E. (1993). Early Miocene rodent faunas from the Eastern Mediterranean area, 3. The genera Depertomys and Cricetodon with a discussion of the evolutionary history of the Cricetodontini. Proceedings Koninklijke Nederlandse Akademie van Wetenschappen B, 96(2), 151-216.

Bruijn, H. de Ünay, E., Saraç, G., \& Klein Hofmeijer, G. (1987). An unusual new Eucricetodontine from the lower Miocene of the eastern Mediterranean. Proceedings of the Koninklijke Nederlandse Akademie Van Wetenschappen, (B), 90(2), 129-132.

Bruijn, H. de Ünay, E., Saraç, G., \& Yilmaz, A. (2003). A rodent assemblage from the Eo/Oligocene boundary interval near Süngülü, Lesser Caucasus, Turkey. In N. López-Martínez, P. PeláezCampomanes, \& M. Hernández Fernández (Eds.), En torno a Fósiles de Mamíferos: Datación, Evolución y Paleoambiente. Coloquios de Paleontología, Volumen Extraordinario no 1. En honor al dr. Remmert Daams (pp. 47-76).

Bruijn, H. de, Mayda, S., Hoek Ostende, L. W. van den, Kaya, T., \& Saraç, G. (2006). Small mammals from the Early Miocene of Sabuncubeli (Manisa, S.W. Anatolia, Turkey). Beiträge zur Paläontologie Österreichs, 30, 57-87.

Bruijn, H. de Hoek Ostende, L. W. van den, \& Donovan, S. K. (2007). Mirrabella, a new name for the genus Mirabella De Bruijn et al., 1987 (Mammalia), preoccupied by Mirabella Emeljanov, 1982 (Insecta). Contributions to Zoology, 76(4), 279-280.

Bruijn, H. de Marković, Z., \& Wessels, W. (2013). Late Oligocene rodents from Banovići (Bosnia and Herzegovina). Palaeodiversity, 6, 63-105.

Bruijn, H. de, Bosma, A. A., \& Wessels, W. (2015). Are the Rhizomyinae and the Spalacinae closely related? Contradistinctive conclusions between genetics and palaeontology. In L. W. van den Hoek Ostende, P. Peláez-Campomanes, \& W. Wessels (Eds.) Old worlds, new ideas. A tribute to Albert van der Meulen. Palaeobiology Palaeoenvironments, 95(3), 257-269. https://doi.org/10.1007/ s12549-015-0195-y.

Bruijn, H. de, Marković, Z., Wessels, W., Milivojević, M., \& Weerd, A. A. van de (2018). Rodent faunas from the Paleogene of south-east Serbia. Palaeobiodiversity and Palaeoenvironments, 98(3), 441458. https://doi.org/10.1007/s12549-017-0305-0.

Buzaljko, R., \& Marković, S. (1985). Basic geological map of Yugoslavia 1:100,000. Map explanation Brčko sheet, L 34-110. Beograd: Socialist Federal Republic of Yugoslavia. [In Serbo-Croatian]

Buzaljko, R., Marković, S., Vujnović, L., \& Olujić, J.; contributions by Čampara, S., Vrhovčić, J., Spasovski, R., Brkić, M., Korolija, B., \& 
Kovačić, M. (1985). Basic geological map of Yugoslavia 1:100, 000; Brčko sheet, L 34-110. Beograd: Socialist Federal Republic of Yugoslavia. [In Serbo-Croatian]

Cicić, S., Jovanović, Ć., Mojićević, M., Tokić, S., \& Dimitrov, P. (1988). Basic geological map of Yugoslavia 1:100,000; Tuzla sheet, L34122, Beograd: Socialist Federal Republic of Yugoslavia. [In SerboCroatian]

Cicić, S., Jovanović, Ć. Mojićević, M., \& Tokić, S. (1991). Basic geological map of Yugoslavia 1:100,000. Map explanation Tuzla sheet, L34-122. Beograd: Socialist Federal Republic of Yugoslavia. [In Serbo-Croatian]

Čičulić, T. M., \& Rakić, M. (1976). Basic geological map of Yugoslavia 1:100,000; Novi Sad sheet L34-112. Beograd: Socialist Federal Republic of Yugoslavia. [In Serbo-Croatian]

Čičulić, T. M., \& Rakić, M. (1977). Basic geological map of Yugoslavia 1:100,000. Map explanation Novi Sad sheet L34-112. Beograd: Socialist Federal Republic of Yugoslavia. [In Serbo-Croatian]

Comte, B. (2000). Rythme et modalités de l'évolution chez les ronguers à la fin de l'Oligocène. Leurs relations avec les changements de l'environnement. Palaeovertebrata, 29(2-4), 83-360.

D’Elía, G., Fabre, P.-H., \& Lessa, E. P. (2019). Rodent systematics in an age of discovery: recent advances and prospects. Journal of Mammalogy, 100(3), 852-871. https://doi.org/10.1093/jmammal/ gyy 179 .

Daams, R., \& de Bruijn, H. (1995). A classification of the Gliridae (Rodentia) on the basis of dental morphology. Hystrix, 6(1-2), 3-50.

Deperet, C., \& Douxami, A. (1902). Les vertebres oligocenes de Pyrimont-Chalonges (Savoie). Abhandlungen der Schweizerischen Palaeontologischen Gesellschaft, 29, 1-91.

Doukas, C. S., \& Theocharopoulos, C. D. (1999). Smaller mammals from the Oligocene of Kyprinos (Thrace, N. Greece). In J. W. F. Reumer \& J. de Vos (Eds.), Elephants have a snorkel! Papers in honour of Paul Y. Sondaar. Deinsea 7, 133-145.

Engesser, B. (1987). New Eomyidae, Dipodidae, and Cricetidae (Rodentia, Mammalia) of the Lower Freshwater Molasse of Switzerland and Savoy. Eclogae Geologicae Helvetiae, 80, 943 994.

Fahlbusch, V. (1964). Die Cricetiden der Oberen Süßwassermolasse Bayerns. Bayerische Akademie der Wissenschaften; mathematischnaturwissenschaftliche Klasse, Abhandlungen. Neue Folge, 11, 1136.

Fischer, G. (1817). Adversaria Zoologica. Mémoires de la Societé Impériale des Naturalistes de Moscou, 5, 357-446.

Flynn, L. J., Jacobs, L. L., \& Cheema, I. U. (1986). Baluchimyinae, a new ctenodactyloid rodent subfamily from the Miocene of Baluchistan. American Museum Novitates, 2841, 1-58.

Flynn, L. J., Jacobs, L. L., Kimura, Y., \& Lindsay, E. H. (2019). Rodent suborders. Fossil Imprint, 75(3-4), 292-298 Praha. ISSN 2533-4050 (print), ISSN 2533-4069 (online).

Freudenberg, H. (1941). Die oberoligocänen Nager von Gaimersheim bei Ingolstadt und ihre Verwandten. Palaeontographica, 92A, 99-164.

Freudenthal, M., \& Martín-Suárez, E. (2007a). Revision of the subfamily Bransatoglirinae (Gliridae, Rodentia, Mammalia). Scripta Geologica, 135, 241-273.

Freudenthal, M., \& Martín-Suárez, E. (2007b). Microdyromys (Gliridae, Rodentia, Mammalia) from the Early Oligocene of Montalbán (Prov. Teruel, Spain). Scripta Geologica, 135, 179-211.

Freudenthal, M., \& Martín-Suárez, E. (2016). A review of Oligocene and early Miocene European Cricetidae (Mammalia). Spanish Journal of Palaeontology, 31(2), 341-352.

Freudenthal, M., \& Martín-Suárez, E. (2017). A revision of European Plesiosminthus (Rodentia, Dipodidae), and new material from the upper Oligocene of Teruel (Spain). Palaeontologia Electronica, 20(2), 41A 1-25.

Gomes Rodrigues, H., Marivaux, L., \& Vianey-Liaud, M. (2013). On the status of early Eucricetodontinae (Muroidea, Rodentia) with a special focus on the Atavocricetodon vs Eucricetodon issue: morphometrical aspects. Spanish Journal of Paleontology, Sociedad Española de Paleontología, 28(1), 17-27.

Gray, J. E. (1821). On the natural arrangement of vertebrose animals. London Medical Repository, 15(1), 296-310.

He, Y., Hu, S., Ge, D., Yang, Q., Connor, T., \& Zhou, C. (2019). Evolutionary history of Spalacidae inferred from fossil occurrences and molecular phylogeny. Mammal Review, 50, 11-24. https://doi. org/10.1111/mam. 12170 .

Heissig, K. (1990). Ein Oberkiefer von Anthracohyus (Mammalia, ?Artiodactyla) aus dem Eozän Jugoslawiens. Mitteilungen der Bayerischen Staatssammlung für Paläontologie und Historische Geologie, 30, 57-64.

Hellmund, M., \& Heissig, K. (1994). Neuere Funde von Prominatherium damatium H. v. Meyer 1854 (Artodactyla, Mammalia) aus dem Eozän von Dalmatien. Mitteilungen der Bayerischen Staatssammlung für Paläontologie und Historische Geologie, 34, 273 281.

Horváth, F., Bada, G., Szafián, P., Tari, G., Ádám, A., \& Cloetingh, S. (2006). Formation and deformation of the Pannonian Basin: Constraints from observational data. In D. G. Gee \& R. A. Stephenson (Eds.), European Lithosphere Dynamics. Geological Society, London, Memoirs 32, 191-206.

Huchon, D., Catzeflis, F. M., \& Douzery, J. P. (2000). Variance of molecular datings, evolution of rodents, and the phylogenetic affinities between Ctenodactylidae and Hystricognathi. Proceedings of the Royal Society B, 267, 393-402. https://doi.org/10.1098/rspb.2000. 1014.

Hugueney, M. (1967). Les Gliridés (Mammalia, Rodentia) de l'Oligocène supérieur de Coderet-Bransat (Allier). Comptes Rendus sommaires Société Géologique de France, 1967(3), 91-92.

Hugueney, M., \& Adrover, R. (1989-90). Rongeurs (Rodentia, Mammalia) de 1'Oligocène de Sineu (Baléares, Espagne). Paleontologia i Evolució, 23, 157-169.

Hugueney, M., \& Mein, P. (1993). A comment on the earliest Spalacinae (Rodentia, Muroidea). Journal of Mammalian Evolution, 1(3), 215 223.

Illiger, C. (1811). Prodromus systematis mammalium et avium additis terminis zoographicis utriusque classis, eorumque versione germanica (pp. 1-301). Berlin: C. Salfeld.

Jansa, S. A., Giarla, T. C., \& Lim, B. K. (2009). The phylogenetic position of the rodent genus Typhlomys and the geographic origin of Muroidea. Journal of Mammalogy, 90, 1083-1094.

Joniak, P., Peláez-Campomanes, P., Hoek Ostende, L. W. van den, \& Rojay, B. (2017). Early Miocene rodents of Gökler (Kazan Basin, Central Anatolia, Turkey). Historical Biology, 31(8), 982-1007 (2019). https://doi.org/10.1080/08912963.2017.1414211.

Kalthoff, D. C. (2000). Die Schmelzmikrostructur in den Incisiven der hamsterartigen Nagetiere und anderer Myomorpha (Rodentia, Mammalia). Palaeontographica, (A), 259, 1-193.

Klein Hofmeijer, G., \& Bruijn, H. de (1985). The mammals from the lower Miocene of Aliveri (Island of Evia, Greece) part IV: The Spalacidae and Anomalomyidae. Proceedings of the Koninklijke Nederlandse Akademie Van Wetenschappen, (B), 88, 185-198.

Koenigswald, W. von (1993). Die Schmelzmuster in den Schneidezähnen der Gliroidea (Gliridae und Seleviniidae, Rodentia, Mammalia) und ihre systematische Bedeutung. Zeitschrift für Säugetierkunde, 58, 92-115.

Koenigswald, W. von (1995). Enamel differentiation in myoxid incisors and their systematic significance. Hystrix, (n.s.), 6(1-2), 99-107.

Krijgsman, W., Duermeijer, C. E., Langereis, C. G., Bruijn, H. de, Saraç, G., \& Andriessen, P. A. M. (1996). Magnetic polarity stratigraphy of Late Oligocene to Middle Miocene mammal-bearing continental deposits in Central Anatolia (Turkey). Newsletters on Stratigraphy, 34(1), 13-29 DOI:007S-0042 1/96/0034-00 13. 
Kristkoiz, A. (1992). Zahnmorphologische und schädelanatomische Untersuchungen an Nagetieren aus dem Oberoligozän von Gaimersheim (Süddeutschland). Abhandlungen der Bayerischen Akademie der Wissenschaften, mathematisch-naturwissenschaftliche Klasse (neue Folge), 167, 1-137.

Lartet, E. (1851). Notice sur la colline de Sansan, suivie d'une récapitulation des diverses espèces d'animaux vertébrés fossiles, trouvés soit á Sansan, soit dans d'autres gisements du terrain tertiaire miocène dans le Bassin Sous-Pyrénéen. J. A. Portes, Auch, 1-41.

Laskarev, V. (1925). La trouvaille des Anthracothérides en Serbie et en Bosnie (pp. 85-91). Beograd: Annales géologique de la Péninsula balkanique.

Leeuw, A. de, Mandic, O., Bruijn, H. de, Marković, Z., Reumer, J., Wessels, W., Šisic, E., \& Krijgsman, W. (2011). Magnetostratigraphy and small mammals of the Late Oligocene Banovici basin in NE Bosnia and Herzegovina. Palaeogeography, Palaeoclimatology, Palaeoecology, $310,400-412$.

López-Antoñanzas, R., Sen, S., \& Saraç, G. (2004). New large ctenodactylid species from the Lower Miocene of Turkey. Journal of Vertebrate Paleontology, 24(3), 676-688.

Malez, M., \& Thenius, E. (1985). Über das Vorkommen von Amynodonten (Rhinocerotoidea, Mammalia) im Oligo-Miocän von Bosnien (Jugoslawien). Paleaontologica Jugoslavica Zagreb, 34, 1-26.

Mandic, O., Sant, K., Ćorić, S., Theobalt, D., Grunert, P., de Leeuw, A., \& Krijgsman, W. (2019). Integrated bio-magnetostratigraphy of the Badenian reference section Ugljevik in southern Pannonian Basin Implications for the Paratethys history (middle Miocene, Central Europe). Global and Planetary Change, 172, 374-395.

Maridet, O., Esgarguel, G., Mein, P., Hugueney, M., \& Legendre, S. (2007). Small mammals (rodents and lagomorphs) European biogeography from the late Oligocene to the mid Pliocene. Global Ecology and Biogeography, 16, 529-544.

Marković, Z., Wessels, W., Weerd, A. A. van de, \& Bruijn, H. de (2019). Deperetomys (Rodentia, Muridae) from the Oligocene of Serbia and Bosnia and Herzegovina. Palaeobiodiversity and Palaeoenvironments. (2020), 100(3), 821-840. https://doi.org/10.1007/ s12549-019-00389-0.

Marković, Z., Wessels, W., Weerd, A. A. van de, \& Bruijn, H. de (2020). Pseudocricetodontinae (Mammalia, Rodentia) from the Paleogene of south-east Serbia. Palaeobiodiversity and Palaeoenvironments, 100(1), 251-267. https://doi.org/10.1007/s12549-019-00373-8.

Mein, P., \& Freudenthal, M. (1971). Une nouvelle classification des Cricetidae (Mammalia, Rodentia) du Tertiaire de l'Europe. Scripta Geologica, 2, 1-35.

Meulenkamp, J. E., \& Sissingh, W. (2003). Tertiary palaeogeography and tectonostratigraphic evolution of the Northern and Southern PeriTethys platforms and the intermediate domains of the AfricanEurasian convergent plate boundary zone. Palaeogeography, Palaeoclimatolology, Palaeoecolology, 196, 209-228.

Mojsilović, S., Filipović, I., Rodin, V., Navala, M., Baklaić, D., Đoković, I., Jovanović, Č., Živanović, D., Eremija, M., \& Cvetković, I. (1968a). Basic geological map of Yugoslavia 1:100,000; Zvornik sheet, L34-123. Beograd: Socialist Federal Republic of Yugoslavia. [In Serbo-Croatian]

Mojsilović, S., Filipović, I., Avramović, V., Rodin, V., Navala, M., Baklaić, D. \& Đoković, I. (1968b). Basic geological map of Yugoslavia 1:100,000. Map explanation Zvornik sheet, L34-123. Beograd: Socialist Federal Republic of Yugoslavia. [In SerboCroatian]

Muirhead, L. (1819). Mazology. In D. Brewster (Ed.), The Edinburgh encyclopaedia. 4th edn. Volume 13 (pp. 393-480), Edinburgh: William Blackwood

Nikolov, I., \& Heissig, K. (1985). Fossile Säugetiere aus dem Obereozän und Unteroligozän Bulgariens und ihre Bedeutung für die
Palaeogeographie. Mitteilungen der Bayerischen Staatssammlung für Paläontologie und historische Geologie, 25, 61-79.

Petković, K., Čičulić-Trifonović, M., Pašić, M., \& Rakić, M. (1976). Fruška Gora Monografski Prikaz Geolośke Gradje i Tektonskog Sklopa, Matica Scripsca Novi Sad. (Fruška Gora). Monographic review of geological materials and tectonic assembly, 267. [In Serbian, with summary in French]

Pezelj, Đ., Mandic, O., \& Ćorić, S. (2013). Paleoenvironmental dynamics in the southern Pannonian Basin during initial Middle Miocene marine flooding. Geologica Carpathica, 64(1), 81-100.

Prieto, J. (2012). Comments on the morphologic and metric variability in the cricetid rodent Deperetomys hagni (Fahlbusch, 1964) from the Middle Miocene of South Germany. Zitteliana, A, 52, 71-77.

Qiu, Z.-D. (1996). Middle Miocene micromammalian fauna from Tunggur. Nei Mongol. Beijing Science Press, 1-216.

Schaub, S. (1925). Die hamsterartigen Nagetiere des Tertiărs und ihre lebenden Verwandten. Abhandlungen Schweizerischen Palaeontologische Gesellschaft, 45, 1-114.

Schaub, S. (1930). Fossile Sicistinae. Eclogae geologicae Helvetiae, 23(2), 616-636.

Schaub, S. (1958). Simplicidentata (= Rodentia). In J. Piveteau (Ed.), Traité de Paléontologie 6(2) (pp. 659-818). Paris: Masson et Cie.

Schlosser, M. (1884). Die Nager des Europäischen Tertiärs. Palaeontographica, 31, 19-162.

Thaler, L. (1966). Les rongeurs fossiles du Bas Languedoc dans leur rapports avec l'histoire des faunes et la stratigraphie d'Europe. Mémoires Musée Histoire Naturelles, nouvelle série, C, 17, 1-295.

Toljić, M., Matenco, L., Ducea, M. N., Stojadinović, U., Milivojević, J., \& Đerić, N. (2013). The evolution of a key segment in the EuropeAdria collision: The Fruška Gora of northern Serbia. Global and Planetary Change, 103, 39-62.

Tullberg, T. (1899). Über das System der Nagetiere: eine phylogenetische Studie. Nova Acta Regiae Societatis Scientiarum Upsaliensis, 18, 1 514.

Ünay, E. (1994). Early Miocene rodent faunas from the eastern Mediterranean area. Part IV: The Gliridae. Proceedings of the Koninklijke Nederlandse Akademie van Wetenschappen, 97(4), 445-490, Amsterdam.

Ünay, E. (1996). On fossil Spalacidae (Rodentia). In R. L. Bernor, V. Fahlbusch, \& H. W. Mittmann (Eds.), The evolution of Western Eurasian Neogene Mammal Faunas. (pp. 246-252). New York: Columbia University Press.

Ünay, E., de Bruijn, H., \& Saraç, G. (2003). The Oligocene rodent record of Anatolia: A review. In J. W. F. Reumer \& W. Wessels (Eds.), Distribution and migration of Tertiary mammals in Eurasia (pp. 531-538). Special Issue: Deinsia (Rotterdam).

Ünay-Bayraktar, E. (1989). Rodents from the Middle Oligocene of Turkish Thrace. Utrecht Micropaleontological Bulletin, Special Publication, 5, 1-119.

Vianey-Liaud, M. (1994). La radiation des Gliridae (Rodentia) à l'Eocène supérieur en Europe Occidentale et sa descendance Oligocène. Münchner Geowissenschaftliche Abhandlungen, A26, 117-160.

Viret, J. (1926). Nouvelles observations relatives à la faune de rongeurs de St Gérand·le·Puy. Comptes rendus Académie des Sciences, Paris, 183, 71-72.

Vrabac, S., Čuculic, V., Mulaosmanović, D., Pavlić, G., \& Okuka, S. (1995). Karakteristike geološke građe ugljonosnih sedimenata $i$ uglja u rejoni Bogutovo Selo kod Ugljevika. [Characteristics of the geological structure of coal-bearing sediments in the Bogutovo Selo region near Ugljevik]. Glasnik Sarajevo, 33, 73-80. [In SerboCroatian, summary in English]

Vrhovčić, J., Mojićević, M., Andjelković, J., Marković, B., Pavlović, Z., Rajčević, D., Prfoljan, B., \& Galović, I. (1985). Basic geological map of Yugoslavia 1:100,000. Bijeljina sheet L34-111. Beograd: Socialist Federal Republic of Yugoslavia. [In Serbo-Croatian] 
Vrhovčić, J., Buzaljko, R., Mojićević, M., Prfoljan, B., Galović, I., Anđelković, J., Marković, B., Pavlović, Z., \& Rajčević, D. (1986). Basic geological map of Yugoslavia 1:100,000. Map explanation Bijeljina sheet L34-111. Beograd: Socialist Federal Republic of Yugoslavia. [In Serbo-Croatian]

Wang, B.-Y. (1985). Zapodidae (Rodentia, Mammalia) from the lower Oligocene of Qujing, Yunnan, China. Mainzer Geowissenschaftliche Mitteilungen, 14, 345-367.

Weerd, A. A. van de, Wessels, W. \& Bruijn, H. de (2021). New rodents from the late Oligocene site of Gözükızıllı in Anatolia (Turkey).
Historical Biology. https://doi.org/10.1080/08912963.2020. $1800682,1,26$.

Wessels, W., van de Weerd, A. A., de Bruijn, H., \& Marković, Z. (2020). Dipodidae (Mammalia, Rodentia) from the Paleogene of south-east Serbia. Palaeobiodiversity and Palaeoenvironments, 100(3), 841848. https://doi.org/10.1007/s12549-019-00392-5.

Publisher's note Springer Nature remains neutral with regard to jurisdictional claims in published maps and institutional affiliations. 